\title{
Article \\ Pentamethylcyclopentadienyl Molybdenum(V) Complexes Derived from Iodoanilines: Synthesis, Structure, and ROP of $\varepsilon$-Caprolactone
}

\author{
Tian Xing ${ }^{1}$, Mark R. J. Elsegood ${ }^{2}\left(\mathbb{D}\right.$, Sophie H. Dale ${ }^{2}$ and Carl Redshaw ${ }^{1, *(\mathbb{D}}$ \\ 1 Plastics Collaboratory, Department of Chemistry, The University of Hull, Cottingham Rd., Hull HU6 7RX, UK; \\ t.Xing-2017@hull.ac.uk \\ 2 Chemistry Department, Loughborough University, Loughborough LE11 3TU, UK; \\ m.r.j.elsegood@lboro.ac.uk (M.R.J.E.); sophiedaleblack@gmail.com (S.H.D.) \\ * Correspondence: c.redshaw@hull.ac.uk; Tel.: +44-1482465219
}

check for updates

Citation: Xing, T.; Elsegood, M.R.J.; Dale, S.H.; Redshaw, C.

Pentamethylcyclopentadienyl

Molybdenum(V) Complexes Derived from Iodoanilines: Synthesis, Structure, and ROP of $\varepsilon$-Caprolactone. Catalysts 2021, 11, 1554. https:// doi.org/10.3390/catal11121554

Academic Editors: Vincenzo Vaiano and Olga Sacco

Received: 19 November 2021

Accepted: 2 December 2021

Published: 20 December 2021

Publisher's Note: MDPI stays neutral with regard to jurisdictional claims in published maps and institutional affiliations.

Copyright: (c) 2021 by the authors. Licensee MDPI, Basel, Switzerland. This article is an open access article distributed under the terms and conditions of the Creative Commons Attribution (CC BY) license (https:/ / creativecommons.org/licenses/by/ $4.0 /)$.
Abstract: The reaction of $\left[\mathrm{Mo}\left(\eta-\mathrm{C}_{5} \mathrm{Me}_{5}\right) \mathrm{Cl}_{4}\right]$ with the ortho-, meta-, or para-iodo-functionalized anilines 2- $\mathrm{IC}_{6} \mathrm{H}_{4} \mathrm{NH}_{2}, 3-\mathrm{IC}_{6} \mathrm{H}_{4} \mathrm{NH}_{2}, 4-\mathrm{IC}_{6} \mathrm{H}_{4} \mathrm{NH}_{2}$ yields imido or amine products of the type $\mathrm{Mo}(\eta-$ $\left.\left.\mathrm{C}_{5} \mathrm{Me}_{5}\right) \mathrm{Cl}_{2}\left(\mathrm{IC}_{6} \mathrm{H}_{4} \mathrm{~N}\right)\right]$ (2-I, 1, 3-I, 3, 4-I, 5) or [ $\left.\mathrm{Mo}\left(\eta-\mathrm{C}_{5} \mathrm{Me}_{5}\right) \mathrm{Cl}_{4}\left(\mathrm{IC}_{6} \mathrm{H}_{4} \mathrm{NH}_{2}\right)\right]$ (3-I, 2, 4-I, 4), respectively, depending on the reaction stoichiometry/conditions; we were unable to isolate an amine complex of the 2-I derivative. The reaction of $\left[\mathrm{Mo}\left(\eta-\mathrm{C}_{5} \mathrm{Me}_{5}\right) \mathrm{Cl}_{4}\right]$ with one equivalent of 2-I,4- $\mathrm{FC}_{6} \mathrm{H}_{3} \mathrm{NH}_{2}$ in the presence of $\mathrm{Et}_{3} \mathrm{~N}$ afforded $\left[\mathrm{Mo}\left(\eta-\mathrm{C}_{5} \mathrm{Me}_{5}\right) \mathrm{Cl}_{2}\left(2-\mathrm{I}, 4-\mathrm{FC}_{6} \mathrm{H}_{3} \mathrm{~N}\right)\right] \cdot \mathrm{MeCN}(6 \cdot \mathrm{MeCN})$, which, upon exposure to air, afforded the $\mathrm{Mo}(\mathrm{VI})$ imido complex $\left[\mathrm{Mo}\left(\eta-\mathrm{C}_{5} \mathrm{Me}_{5}\right) \mathrm{Cl}_{3}\left(2-\mathrm{I}, 4-\mathrm{FC}_{6} \mathrm{H}_{3} \mathrm{~N}\right)\right]$ (7). For comparative studies, the structure of the aniline $\left(\mathrm{C}_{6} \mathrm{H}_{5} \mathrm{NH}_{2}\right)$-derived complex $\left[\mathrm{Mo}\left(\eta-\mathrm{C}_{5} \mathrm{Me}_{5}\right) \mathrm{Cl}_{2}\left(2-\mathrm{C}_{6} \mathrm{H}_{3} \mathrm{~N}\right)\right](8)$ has also been prepared. The molecular structures of $\mathbf{1 - 8} \mathbf{8}$ have been determined and reveal packing in the form of zig-zag chains or ladders. The complexes catalyze, in the presence of benzyl alcohol under $\mathrm{N}_{2}$, the ring-opening polymerization (ROP) of $\varepsilon$-caprolactone affording relatively low molecular weight products. The MALDI-ToF spectra indicate that a number of polymer series bearing a variety of end groups are formed. Conducting the ROPs as melts or under air results in the isolation of higher molecular weight products, again bearing a variety of end groups. Kinetic studies reveal the aniline-derived imido complex 8 performs best, whilst a meta-iodo substituent and a $\mathrm{Mo}(\mathrm{V})$ centre are also found to be beneficial. The structures of the side products $2-\mathrm{IC}_{6} \mathrm{H}_{4} \mathrm{NH}_{3} \mathrm{Cl}$ and $3-\mathrm{IC}_{6} \mathrm{H}_{4} \mathrm{NH}_{3} \mathrm{Cl}$ are also reported.

Keywords: imido; amine; iodo; molybdenum; structure; ring opening polymerization

\section{Introduction}

Molybdenum, and to a lesser extent tungsten, organoimido chemistry has been of interest for a number of decades now, given its relevance to a number of areas, particularly olefin metathesis [1]. Although the literature on imido-containing compounds is vast, reports concerning the synthesis of functionalized imido complexes are less widespread [2]. We have previously investigated the chemistry of $\left[\mathrm{W}\left(\eta-\mathrm{C}_{5} \mathrm{Me}_{5}\right) \mathrm{Cl}_{4}\right]$ as an entry point to new half-sandwich species and have reported the structures of a number of products, including the diamido complex $\left\{\mathrm{W}\left(\eta-\mathrm{C}_{5} \mathrm{Me}_{5}\right) \mathrm{Cl}_{2}\left[1,2-(\mathrm{HN})_{2} \mathrm{C}_{6} \mathrm{H}_{4}\right]\right\}$ [3], as well as imido, hydrazido, amino acid derived chelates [4], and functionalized 6,12-epiiminodibenzo[b,f][1.5]diazocine ligands [5]. The complex $\left[\mathrm{Mo}\left(\eta-\mathrm{C}_{5} \mathrm{Me}_{5}\right) \mathrm{Cl}_{4}\right]$ is prepared by a similar procedure to its tungsten analogue [6], and its chemistry is similarly relatively unexplored [7-12]. We and others have also been exploring the potential of molybdenum-based complexes as catalysts for the ring opening polymerization (ROP) of cyclic esters [13-22]. We were attracted to the use of iodo-substituted organomido groups as a stabilizing motif given their tendency to be involved in intermolecular bonding in the solid state. Such interactions are useful for crystal engineering, halogen-catalyzed reactions, and even in drug design [23-25]. Furthermore, early transition metal imido complexes are known to be quite reactive [26]. 
Herein, we find that the presence of the iodo-substituted organoimido groups does indeed aid the formation of intermolecular interactions in the solid state, and adoption of zig-zag chains or ladder motifs. Furthermore, such systems are capable of acting as catalysts, in the presence of benzyl alcohol, for the ring opening polymerization (ROP) of $\varepsilon$-caprolactone $(\varepsilon-C L)$ at elevated temperatures, either under $\mathrm{N}_{2}$ or air, or as melts. The iodo-containing imido complexes prepared herein are shown in Scheme 1.

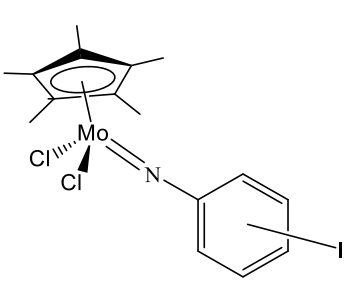

2-I (1), 3-I (3), 4-I (5)

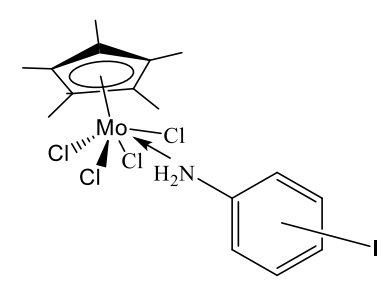

3-I (2), 4-I (4)

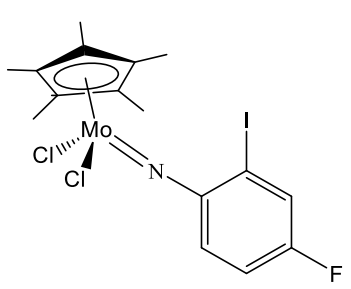

(6)

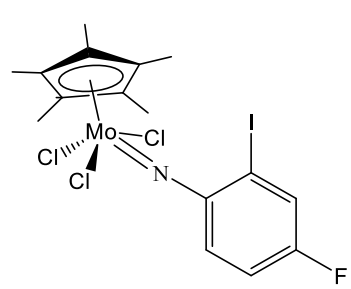

(7)

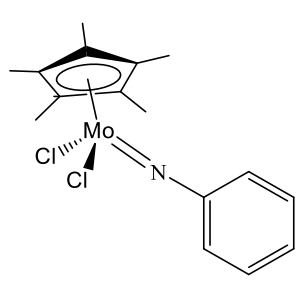

(8)

Scheme 1. Complexes 1-8 prepared herein.

\section{Results}

\subsection{2-Iodo Complexes}

The interaction of $\left[\mathrm{Mo}\left(\eta-\mathrm{C}_{5} \mathrm{Me}_{5}\right) \mathrm{Cl}_{4}\right]$ with two equivalents of 2-iodoaniline, $2-\mathrm{IC}_{6} \mathrm{H}_{4} \mathrm{NH}_{2}$ in refluxing toluene afforded, following work-up in acetonitrile, the imido complex $[\mathrm{Mo}(\eta$ $\left.\left.\mathrm{C}_{5} \mathrm{Me}_{5}\right) \mathrm{Cl}_{2}\left(2-\mathrm{IC}_{6} \mathrm{H}_{4} \mathrm{~N}\right)\right](1)$ in good yield (ca. 76\%). Small, single crystals, suitable for an $\mathrm{X}$-ray structure determination using synchrotron radiation, were obtained on prolonged standing (2-3 days) at ambient temperature. The molecular structure is shown in Figure 1, with selected bond lengths and angles given in the caption. The asymmetric unit contains one molecule of the molybdenum complex. The geometry of the molecule is a three-legged piano stool, typical of such organometal imido dichlorides [11]. The distance from the $C p^{*}$ ring centroid to $\mathrm{Mo}(1)$ is $2.045(3) \AA$, whilst $C(1)>C(5)$ are co-planar within $0.021 \AA$. Meanwhile, the methyl groups all tilt away from the metal, and of these, the most marked is that for $\mathrm{C}(7)$, which is under $\mathrm{N}(1)$, and $\mathrm{C}(10)$ under $\mathrm{Cl}(1)$. Bonds $\mathrm{Mo}(1)-\mathrm{C}(4)$ and $\mathrm{Mo}(1)-$ $\mathrm{C}(5)$ trans to $\mathrm{N}$ are longer than those trans to the $\mathrm{Cl}$ ligands. The ring slippage can be measured by the $\tau$ value [3], which, here, is $3.5^{\circ}$. The organoimido ligand is somewhat bent at $159.8(4)^{\circ}$, but is still considered linear, albeit at the lower end [27].

In the packing of $\mathbf{1}$, there are some weak $\mathrm{I}(1) \cdots \mathrm{Cl}(2)$ halogen bond interactions at $3.738 \AA$ which result in zig-zag chains parallel to $b$ (Figure 2). For alternative views of $\mathbf{1}$, see Figure S1.

The side product in this reaction is the salt $\left[2-\mathrm{I}-\mathrm{NH}_{3} \mathrm{C}_{6} \mathrm{H}_{4}\right]^{+} \mathrm{Cl}^{-}$. It, too, has an interesting structure, involving a number of intermolecular interactions. In the asymmetric unit, there is one cation/anion pair, in which all three of the $\mathrm{NH}$ protons are involved in strong $\mathrm{H}$-bonds to the chloride anion. Unlike in [2-I- $\left.\mathrm{NH}_{3} \mathrm{C}_{6} \mathrm{H}_{4}\right]^{+} \mathrm{Cl}^{-}$vide infra, there are no I $\cdots \mathrm{I}$ halogen-halogen interactions, instead there are $\mathrm{Cl} \cdots \mathrm{I}$ interactions at $3.306 \AA$. There are no $\pi \cdots \pi$ interactions; at best the molecules are highly slipped, forming a layered structure with alternating hydrophilic ionic and hydrophobic aromatic layers. The ionic layers are in the $b / c$ plane, see Figure S2. 


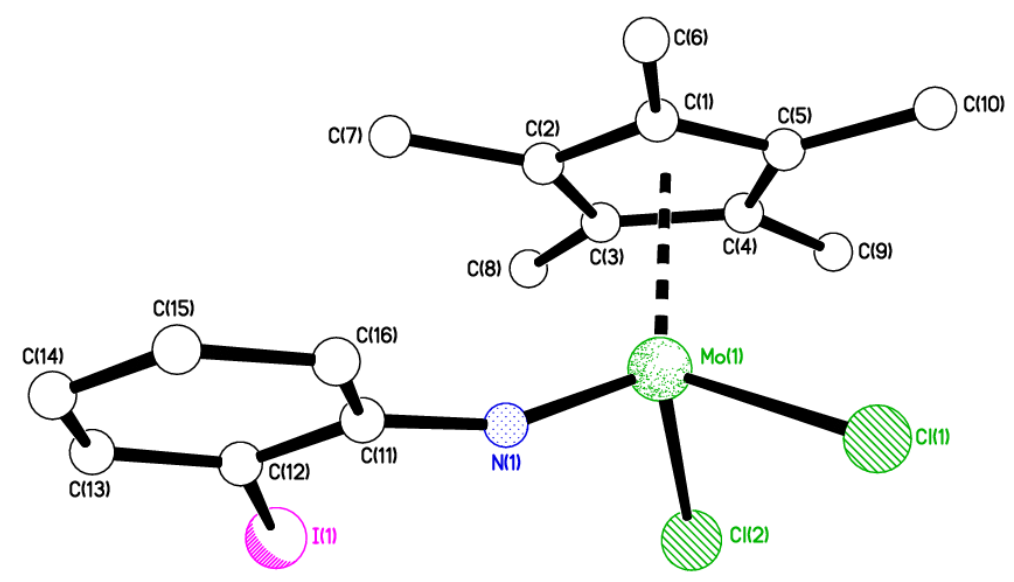

Figure 1. Molecular structure of $\left[\mathrm{Mo}\left(\eta-\mathrm{C}_{5} \mathrm{Me}_{5}\right) \mathrm{Cl}_{2}\left(2-\mathrm{IC}_{6} \mathrm{H}_{4} \mathrm{~N}\right)\right](\mathbf{1})$. $\mathrm{H}$ atoms omitted for clarity. Selected bond lengths $(\AA)$ and angles $\left(^{\circ}\right)$ : $\mathrm{Mo}(1)-\mathrm{Cl}(1) 2.3636(18), \mathrm{Mo}(1)-\mathrm{Cl}(2)$ 2.3634(15), $\mathrm{Mo}(1)-\mathrm{N}(1)$ 1.756(4); $\mathrm{Mo}(1)-\mathrm{N}(1)-\mathrm{C}(11)$ 159.8(4), Cl(1)-Mo(1)-Cl(2) 92.92(7).
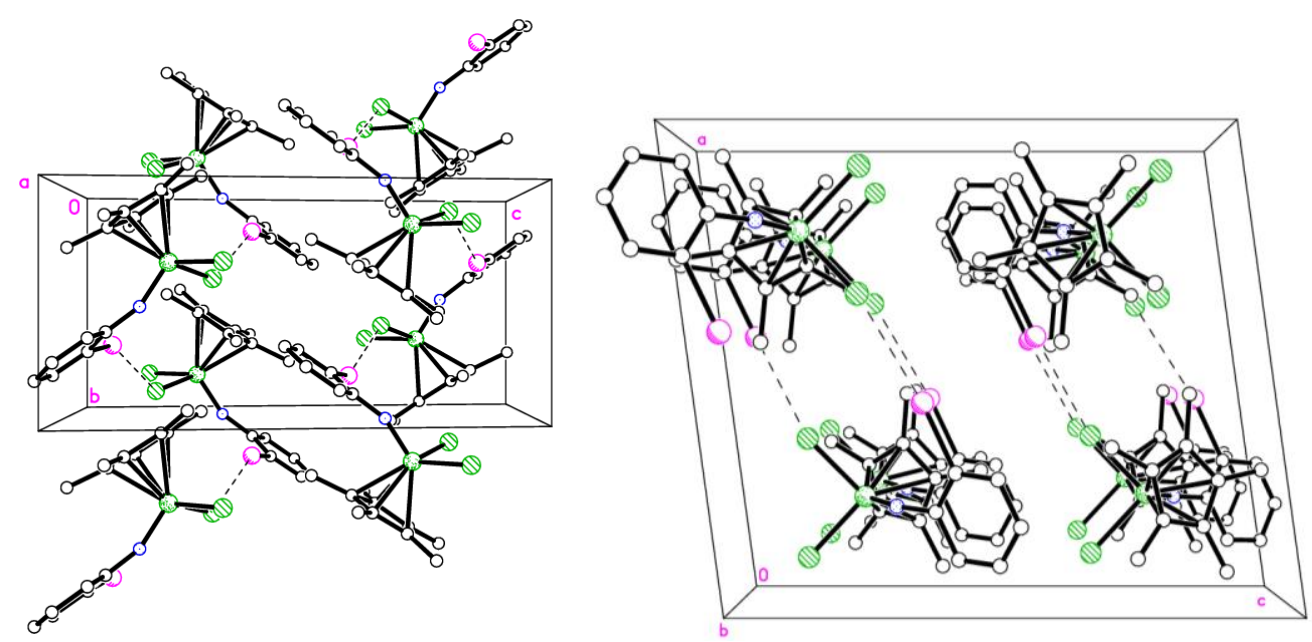

Figure 2. Packing observed in $\mathbf{1}$ with halogen-bonded zig-zag chains in the $b$ direction.

\subsection{3-Iodo Complexes}

Treatment of $\left[\mathrm{Mo}\left(\eta-\mathrm{C}_{5} \mathrm{Me}_{5}\right) \mathrm{Cl}_{4}\right]$ with one equivalent of the meta aniline $3-\mathrm{IC}_{6} \mathrm{H}_{4} \mathrm{NH}_{2}$ at ambient temperature led, following work-up, to isolation of the amine complex [Mo( $\eta$ $\left.\left.\mathrm{C}_{5} \mathrm{Me}_{5}\right) \mathrm{Cl}_{4}\left(3-\mathrm{IC}_{6} \mathrm{H}_{4} \mathrm{NH}_{2}\right)\right] \cdot \mathrm{MeCN}(2 \cdot \mathrm{MeCN})$. The IR spectrum of 2 contains two sharp (weak) stretches in the N-H region, at 3415 and $3328 \mathrm{~cm}^{-1}$, characteristic of the $\mathrm{NH}_{2}$ group. As for 1 and 3 (see below), the ${ }^{1} \mathrm{H}$ NMR spectrum is broad and uninformative consistent with the presence of the paramagnetic $\mathrm{Mo}(\mathrm{V})$ centre. The molecular structure of 2. $\mathrm{MeCN}$ is shown in Figure 3, with selected bond lengths and angles given in the caption. The asymmetric unit contains one molecule of the molybdenum complex and a solvent $(\mathrm{MeCN})$ molecule of crystallisation. The geometry at the metal is best described as distorted octahedral with the Mo ion $0.5783(18) \AA$ out of the $\mathrm{Cl}_{4}$ plane. The Mo to $\mathrm{Cp}^{*}$ ring centroid distance is 2.078(6) $\AA$ and all the methyl groups bend substantially away from the $C_{5}$ aromatic ring, by $0.14-0.22(2) \AA$; the $\tau$ value is $3.3^{\circ}$. In contrast to 1 , here the aniline-derived ligand maintains the amine group, hence the elongated Mo-N bond length at 2.322(10) A. 


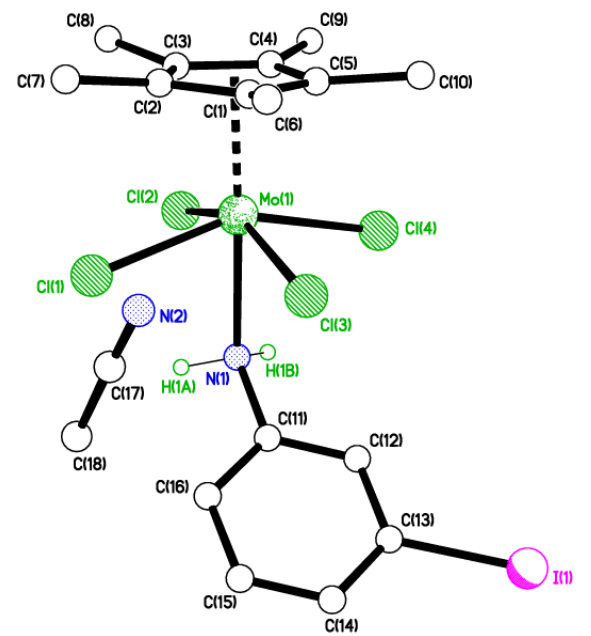

Figure 3. Molecular structure of $\left[\mathrm{Mo}\left(\eta-\mathrm{C}_{5} \mathrm{Me}_{5}\right) \mathrm{Cl}_{4}\left(3-\mathrm{IC}_{6} \mathrm{H}_{4} \mathrm{NH}_{2}\right)\right] \cdot \mathrm{MeCN}(\mathbf{2} \cdot \mathrm{MeCN})$. Most $\mathrm{H}$ atoms omitted for clarity. Selected bond lengths $(\AA)$ and angles $\left({ }^{\circ}\right): \operatorname{Mo}(1)-\mathrm{Cl}(1) 2.407(3), \operatorname{Mo}(1)-\mathrm{Cl}(2)$ 2.413(3), $\mathrm{Mo}(1)-\mathrm{Cl}(3)$ 2.376(3), $\mathrm{Mo}(1)-\mathrm{Cl}(4)$ 2.420(3), $\mathrm{Mo}(1)-\mathrm{N}(1)$ 2.322(10); $\mathrm{Mo}(1)-\mathrm{N}(1)-\mathrm{Cl}(1)$ 124.8(7), $\mathrm{Cl}(1)-\mathrm{Mo}(1)-\mathrm{Cl}(2)$ 86.85(10), $\mathrm{Cl}(1)-\mathrm{Mo}(1)-\mathrm{Cl}(4)$ 151.67(11).

The Mo complex molecules form H-bonded zig-zag ladders in the crystallographic a direction. Each complex forms four strong $\mathrm{H}$-bonds, two as donor and two as acceptor. These are via two independent $\mathrm{N}-\mathrm{H} \cdots \mathrm{Cl}^{\prime} \mathrm{H}$-bonds (see Figure 4). There are also two weaker, supporting, aromatic ortho-C $-\mathrm{H} \cdots \mathrm{Cl}$ interactions along the ladders. Otherwise, there are only weak interactions involving $\mathrm{C}-\mathrm{H}$ hydrogens between ladders. The MeCN solvent molecule of crystallization forms a weak N...I interaction at $3.22 \AA$ (see Figure S3).

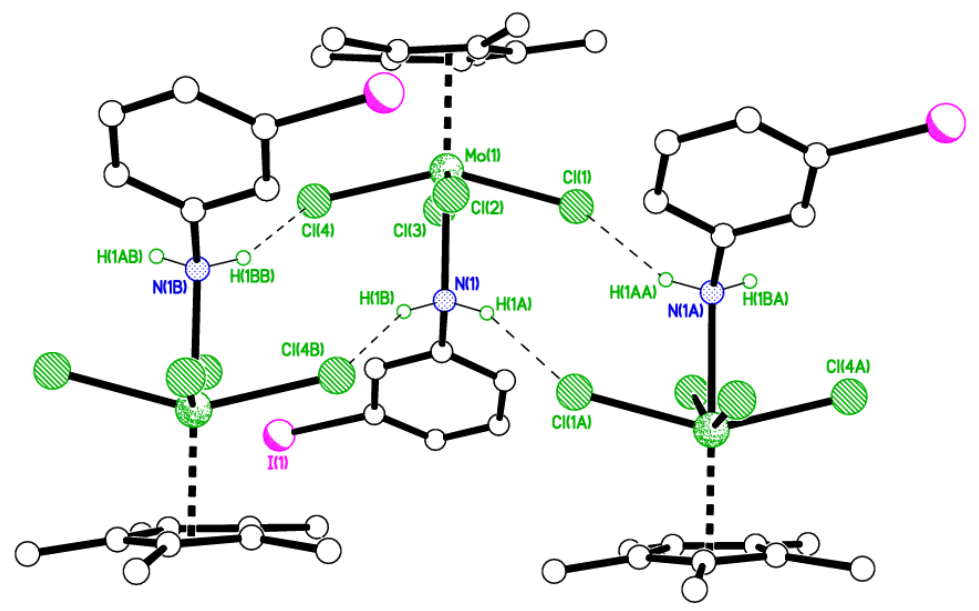

Figure 4. Independent $\mathrm{N}-\mathrm{H} \cdots \mathrm{Cl}^{\prime} \mathrm{H}$-bonds in $2 \cdot \mathrm{MeCN}$ forming ladder motifs. Symmetry operators: $\mathrm{A}=-\mathrm{x}+1,-\mathrm{y}+1,-\mathrm{z}+1 ; \mathrm{B}=-\mathrm{x}+2,-\mathrm{y}+1,-\mathrm{z}+1$.

As for 1, use of three equivalents under reflux conditions affords an imido complex, namely $\left[\mathrm{Mo}\left(\eta-\mathrm{C}_{5} \mathrm{Me}_{5}\right) \mathrm{Cl}_{2}\left(3-\mathrm{I}-\mathrm{NC}_{6} \mathrm{H}_{4}\right)\right](3)$, see Figure 5. In the asymmetric unit, there is one molecule of 1 . The distance from $\mathrm{Mo}(1)$ to the $\mathrm{Cp}^{*}$ ring centroid is 2.0233(7) $\AA$. All the methyl groups bend a little away from the metal relative to the $C_{5}$ ring by between 0.06-0.12 $\AA$, whilst the $C(3) \& C(4)$ bond lengths to $M o(1)$ are the longest because they are trans to $\mathrm{N}(1)$; the $\tau$ value is $3.9^{\circ}$. 


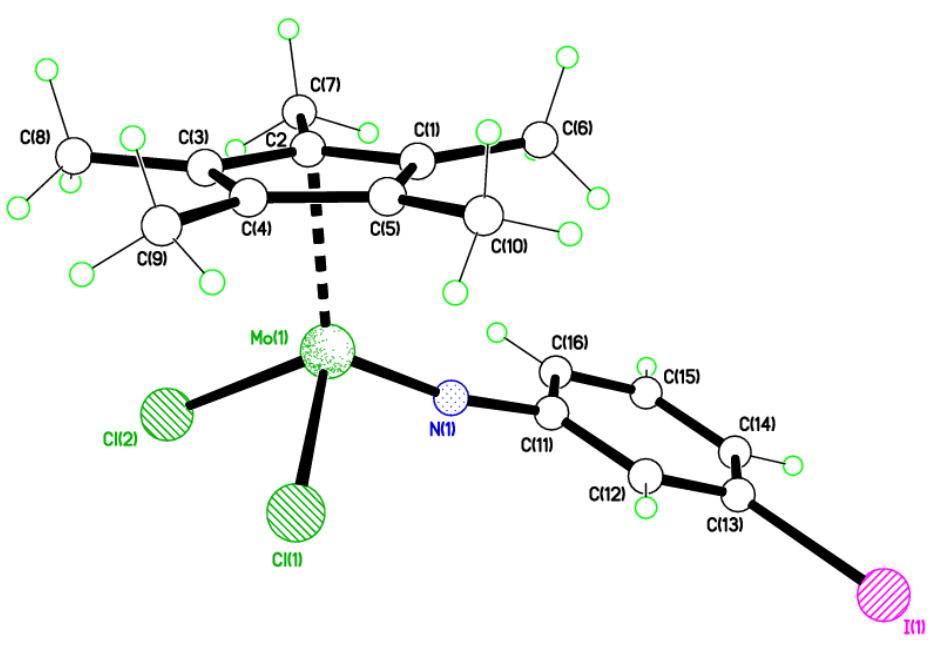

Figure 5. Molecular structure of $\left[\mathrm{Mo}\left(\eta-\mathrm{C}_{5} \mathrm{Me}_{5}\right) \mathrm{Cl}_{2}\left(3-\mathrm{IC}_{6} \mathrm{H}_{4} \mathrm{~N}\right)\right](3)$. Selected bond lengths $(\AA)$ and angles $\left({ }^{\circ}\right)$ : $\mathrm{Mo}(1)-\mathrm{Cl}(1) 2.3722(4), \mathrm{Mo}(1)-\mathrm{Cl}(2)$ 2.3724(4), $\mathrm{Mo}(1)-\mathrm{N}(1)$ 1.7423(13); $\mathrm{Mo}(1)-\mathrm{N}(1)-\mathrm{Cl}(1)$ 169.50(12), $\mathrm{Cl}(1)-\mathrm{Mo}(1)-\mathrm{Cl}(2)$ 93.507(15).

There are a number of weak $(\mathrm{Me}) \mathrm{C}-\mathrm{H} \cdots \mathrm{I} / \mathrm{Cl}$ interactions between molecules of 3 . The molecules pack in weakly-bound layers in the $b / c$ plane (Figure S4). The shortest, and only feasible halogen-halogen interaction is $\mathrm{Cl}(1) \cdots \mathrm{I}\left(1^{\prime}\right)$ at $3.464 \AA$.

For the secondary product, namely $\left[3-\mathrm{I}-\mathrm{NH}_{3} \mathrm{C}_{6} \mathrm{H}_{4}\right]^{+} \mathrm{Cl}^{-}$, there is one cation/anion pair in the asymmetric unit. Within the salt, the ions form strongly H-bonded stacks/layers via ${ }^{+} \mathrm{N}-\mathrm{H} \cdots \mathrm{Cl}^{-}$interactions in the $a$ and $b$ directions. Among the $\mathrm{NH}$ hydrogen atoms, two form fairly strong, single $\mathrm{N}-\mathrm{H} \cdots \mathrm{Cl} \mathrm{H}$-bonds, while the last is bifurcated to two different $\mathrm{Cl}^{-}$ions, and, hence, all these are notably weaker. Moreover, in the $b$ direction, there are zig-zag I ...I interactions at $3.890 \AA$, and overall a 3D supramolecular network is formed (Figure S5).

\subsection{4-Iodo Complexes}

Extension of this chemistry to the para iodoaniline 4- $\mathrm{IC}_{6} \mathrm{H}_{4} \mathrm{NH}_{2}$ led, following the conditions used for 2 , to isolation of the amine complex $\left[\mathrm{Mo}\left(\eta-\mathrm{C}_{5} \mathrm{Me}_{5}\right) \mathrm{Cl}_{4}\left(4-\mathrm{IC}_{6} \mathrm{H}_{4} \mathrm{NH}_{2}\right)\right]$ (4). The IR spectrum of 4 contains two weak stretches in the $\mathrm{N}-\mathrm{H}$ region, at 3318 and $3286 \mathrm{~cm}^{-1}$, characteristic of the $\mathrm{NH}_{2}$ group. Unlike 2, this complex crystallizes without any solvent of crystallization. The molecular structure of 4 is shown in Figure 6, with selected bond lengths and angles given in the caption. The distorted octahedral Mo ion lies 0.5750 (5) $\AA$ out of the $\mathrm{Cl}_{4}$ plane. The $\mathrm{Mo}(1)$ to $C \mathrm{p}^{*}$ ring centroid distance is 2.0826(15) $\AA$ ( $c f$ 2.078(6) in amine complex 2), and the methyl carbons are pushed between 0.173-0.215(6) $\AA$ away from the $\mathrm{Cp}^{*}$ ring plane in the direction away from the metal ion; the $\tau$ value is $3.3^{\circ}$. As in 2, the aniline-derived ligand is an amine with Mo-N at 2.340(3) $\AA$.

As in 2, molecules form zig-zag ladders via strong $\mathrm{N}-\mathrm{H} \cdots \mathrm{Cl} \mathrm{H}$-bonds in the $b$ direction, with each molecule forming four such interactions, two as donor and two as acceptor (see Figure 7). The location of the iodine atom in either the meta or para position allows the ladder motif to form. In addition, in 4 , there are some weak aromatic $\mathrm{C}-\mathrm{H} \cdots \mathrm{X}$ interactions either along ladders or between ladders. These involve all four of the hydrogens on the halogenated ring (Figure S6). 


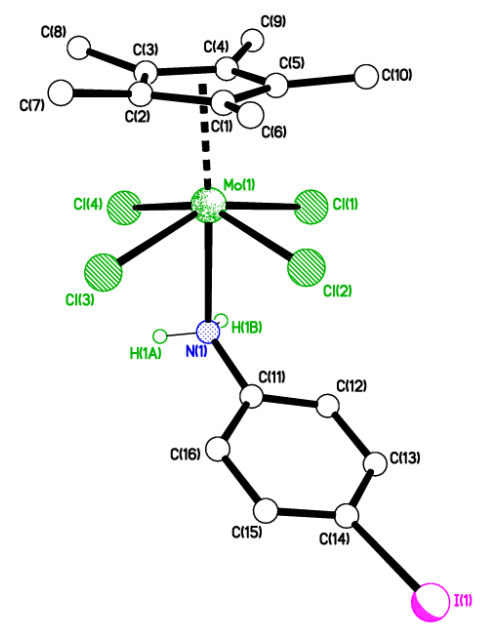

Figure 6. Molecular structure of $\left[\mathrm{Mo}\left(\eta-\mathrm{C}_{5} \mathrm{Me}_{5}\right) \mathrm{Cl}_{4}\left(4-\mathrm{IC}_{6} \mathrm{H}_{4} \mathrm{NH}_{2}\right)\right](4)$. Most $\mathrm{H}$ atoms omitted for clarity. Selected bond lengths $(\AA)$ and angles $\left(^{\circ}\right)$ : $\mathrm{Mo}(1)-\mathrm{Cl}(1) 2.4181(9), \operatorname{Mo}(1)-\mathrm{Cl}(2) 2.3771(10)$, $\mathrm{Mo}(1)-\mathrm{Cl}(3)$ 2.4063(9), $\mathrm{Mo}(1)-\mathrm{Cl}(4)$ 2.4403(10), $\mathrm{Mo}(1)-\mathrm{N}(1)$ 2.340(3); $\mathrm{Mo}(1)-\mathrm{N}(1)-\mathrm{Cl}(1)$ 123.1(2), $\mathrm{Cl}(1)-$ $\mathrm{Mo}(1)-\mathrm{Cl}(2)$ 84.80(3), $\mathrm{Cl}(1)-\mathrm{Mo}(1)-\mathrm{Cl}(4)$ 86.66(3).

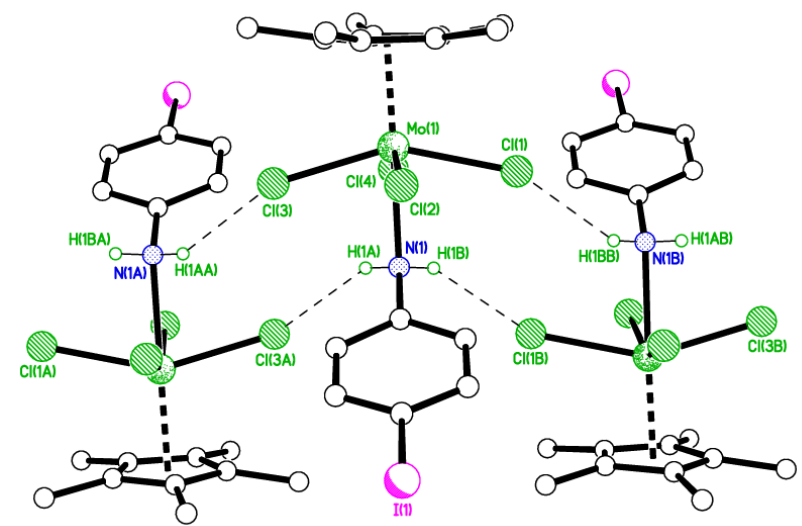

Figure 7. Packing observed in 4 with the same $\mathrm{H}$-bonded ladder motif observed for $2 \cdot \mathrm{MeCN}$. Symmetry operators: $\mathrm{A}=-\mathrm{x}+1,-\mathrm{y}+1,-\mathrm{z}+1 ; \mathrm{B}=-\mathrm{x}+1,-\mathrm{y}+2,-\mathrm{z}+1$.

Use of three equivalents of 4-iodoaniline in refluxing toluene led, on work-up, to the imido complex $\left[\mathrm{Mo}\left(\eta-\mathrm{C}_{5} \mathrm{Me}_{5}\right) \mathrm{Cl}_{2}\left(p-\mathrm{NC}_{6} \mathrm{H}_{4} \mathrm{I}\right)\right](5)$ as dark prisms in ca. $60 \%$ isolated yield. In the crystal structure there is one molecule in the asymmetric unit (Figure 8). The distance from $\mathrm{Mo}(1)$ to the $C \mathrm{p}^{*}$ ring plane is 2.034(2) $\AA$, which compares favorably with the other imido complexes 1 (2.045(3) $\AA$ ) and 3 (2.0233(7) $\AA$ ). The Me groups all point a little away from the metal relative to the $\mathrm{Cp}^{*}$ ring plane, with $\mathrm{C}(12)$ pushed further away than the other four due to the location of the imido ligand; the $\tau$ value is $4.8^{\circ}$. The $\mathrm{Mo}(1)-\mathrm{C}(9) / \mathrm{C}(10)$ distances are rather longer than the other three due to the trans influence at $\mathrm{N}$.

In the packing of 5, there are halogen bond interactions between $\mathrm{I}(1)$ and $\mathrm{Cl}\left(2^{\prime}\right)$ on a neighboring molecule at a distance of $3.431 \AA$. This gives rise to zig-zag chains propagating in the $c$ direction (Figure S7). 


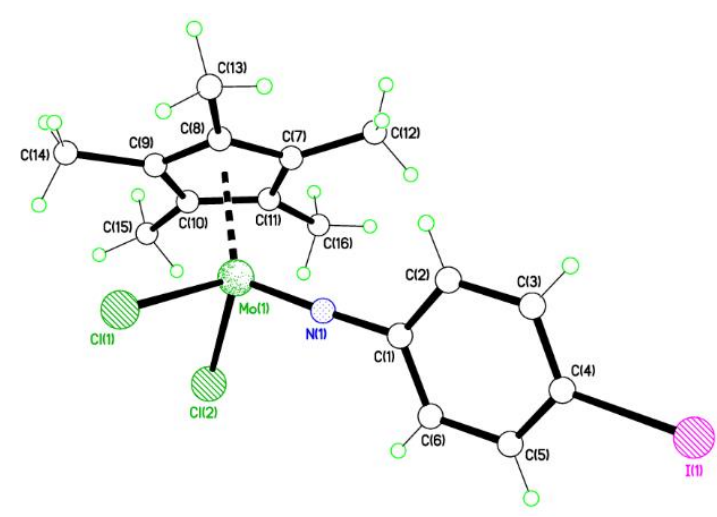

Figure 8. Molecular structure of $\left[\mathrm{Mo}\left(\eta-\mathrm{C}_{5} \mathrm{Me}_{5}\right) \mathrm{Cl}_{2}\left(4-\mathrm{IC}_{6} \mathrm{H}_{4} \mathrm{~N}\right)\right](5)$. Selected bond lengths $(\AA)$ and angles $\left({ }^{\circ}\right)$ : $\mathrm{Mo}(1)-\mathrm{Cl}(1)$ 2.3676(12), $\mathrm{Mo}(1)-\mathrm{Cl}(2)$ 2.3646(11), $\mathrm{Mo}(1)-\mathrm{N}(1)$ 1.739(4); $\mathrm{Mo}(1)-\mathrm{N}(1)-\mathrm{C}(1)$ 175.6(4), $\mathrm{Cl}(1)-\mathrm{Mo}(1)-\mathrm{Cl}(2) 92.66(4)$.

\subsection{Use of 2-I,4- $\mathrm{FC}_{6} \mathrm{H}_{3} \mathrm{NH}_{2}$}

Reactions using this aniline proved to be more sensitive than others employed herein. It was found that to avoid oxidation (see 7), it was better to mix $\left[\mathrm{Mo}\left(\eta-\mathrm{C}_{5} \mathrm{Me}_{5}\right) \mathrm{Cl}_{4}\right]$ with one equivalent of 2-I,4- $\mathrm{FC}_{6} \mathrm{H}_{3} \mathrm{NH}_{2}$ in the presence of $\mathrm{Et}_{3} \mathrm{~N}$ in toluene at ambient temperature. Work-up as before (i.e., extraction into $\mathrm{MeCN}$ ) afforded orange/brown crystals on standing. The molecular structure of $\left[\mathrm{Mo}\left(\eta-\mathrm{C}_{5} \mathrm{Me}_{5}\right) \mathrm{Cl}_{2}\left(2-\mathrm{I}, 4-\mathrm{FC}_{6} \mathrm{H}_{3} \mathrm{~N}\right)\right] \cdot \mathrm{MeCN}(6 \cdot \mathrm{MeCN})$ is shown in Figure 9, with selected bond lengths and angles given in the caption. This is the asymmetric unit. The Mo(1) to ring centroid distance is 2.0375(7) $\AA$. All of the Me groups point away from the $\mathrm{Mo}(\mathrm{V})$ ion, with $\mathrm{C}(15)$ furthest displaced due to the proximity of the large imido ligand; the $\tau$ value is $4.4^{\circ}$. As seen for the other complexes, $C(7)$ and $C(8)$ are notably further from the Mo than the other three $\mathrm{C}$ atoms in the ring due to the trans influence of the $\mathrm{N}$ atom.
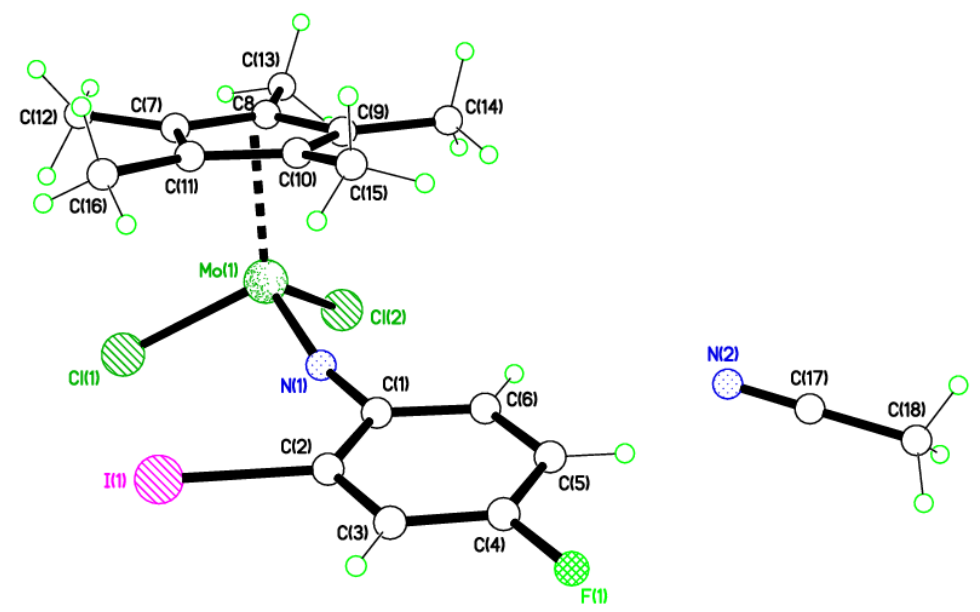

Figure 9. Molecular structure of $\left[\mathrm{Mo}\left(\eta-\mathrm{C}_{5} \mathrm{Me}_{5}\right) \mathrm{Cl}_{2}\left(2 \mathrm{I}, 4 \mathrm{~F}-\mathrm{C}_{6} \mathrm{H}_{3} \mathrm{~N}\right)\right] \cdot \mathrm{MeCN}(\mathbf{6} \cdot \mathrm{MeCN})$. Selected bond lengths $(\AA)$ and angles $\left(^{\circ}\right)$ : $\mathrm{Mo}(1)-\mathrm{Cl}(1)$ 2.3646(4), $\mathrm{Mo}(1)-\mathrm{Cl}(2)$ 2.3727(4), $\mathrm{Mo}(1)-\mathrm{N}(1)$ 1.7483(13); $\mathrm{Mo}(1)-\mathrm{N}(1)-\mathrm{C}(1)$ 165.03(11), $\mathrm{Cl}(1)-\mathrm{Mo}(1)-\mathrm{Cl}(2)$ 92.402(14).

Molecules of $6 \cdot \mathrm{MeCN}$ pack in $\mathrm{H}$-bonded tapes in the $b$ direction. There is an intermolecular I $(1) \cdots \mathrm{Cl}\left(2^{\prime}\right)$ halogen bond with separation $3.486 \AA$. For an alternative view of 6. $\mathrm{MeCN}$ and different views of the packing, see Figure S8.

Oxidized product: Consistent use of three equivalents of 2-I,4- $\mathrm{FC}_{6} \mathrm{H}_{3} \mathrm{NH}_{2}$ afforded, following work up, the diamagnetic complex $\left[\mathrm{Mo}\left(\eta-\mathrm{C}_{5} \mathrm{Me}_{5}\right) \mathrm{Cl}_{3}\left(2-\mathrm{I}, 4-\mathrm{F}-\mathrm{NC}_{6} \mathrm{H}_{3}\right)\right]$ (7). Presumably, here the complex has been oxidized by adventitious exposure to the atmosphere resulting in the formation of a $\mathrm{Mo}(\mathrm{VI})$ centre. We note that the complex $\left[\mathrm{W}\left(\eta-\mathrm{C}_{5} \mathrm{Me}_{5}\right)\right.$ $\left.\left(\mathrm{NC}_{6} \mathrm{~F}_{5}\right) \mathrm{Cl}_{3}\right]$ has been isolated from exposure of $\left[\mathrm{W}\left(\mathrm{\eta}-\mathrm{C}_{5} \mathrm{Me}_{5}\right)\left(\mathrm{NC}_{6} \mathrm{~F}_{5}\right) \mathrm{Cl}_{2}\right]$ to air [11]. The molecular structure of 7 is shown in Figure 10, with selected bond lengths and angles given 
in the caption. The geometry is a four-legged piano stool in which the $\mathrm{Cp}^{*}$ centroid lies 2.071(3) $\AA$ from $\mathrm{Mo}(1)$ and is considerably slipped with a large variation in $\mathrm{Mo}(1)-\mathrm{C}$ bond lengths from 2.300(6) $\AA$ for $\mathrm{C}(5)$ to 2.546(7) $\AA$ for $\mathrm{C}(2)$, which lies trans to $\mathrm{N}(1)$, itself having a strong trans influence. All five methyl groups are pushed away from the aromatic $\mathrm{C}_{5}$ plane, with $C(7)$ less affected than the four others. The displacements away from the $C_{5}$ plane $(\AA)$ are $0.166(12) C(6), 0.052(12) C(7), 0.185(12) C(8), 0.139(12) C(9), 0.176(12) C(10)$. There is a degree of variation, i.e., localization in the $C_{5} C-C$ distances with $C(1)-C(5)$ and $\mathrm{C}(3)-\mathrm{C}(4)$, being longer at ca. $1.45 \AA$ than the other three at ca. $1.41-1.42 \AA$; the $\tau$ value is $7.6^{\circ}$.

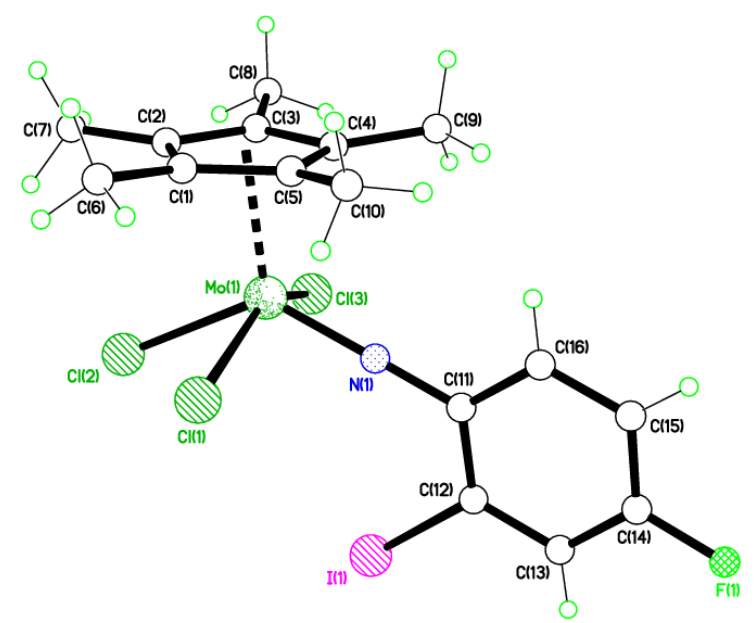

Figure 10. Molecular structure of $\left[\mathrm{Mo}\left(\eta-\mathrm{C}_{5} \mathrm{Me}_{5}\right) \mathrm{Cl}_{3}\left(2-\mathrm{I}, 4-\mathrm{F}-\mathrm{NC}_{6} \mathrm{H}_{3}\right)\right]$ (7). Selected bond lengths $(\AA)$ and angles $\left(^{\circ}\right): \mathrm{Mo}(1)-\mathrm{Cl}(1)$ 2.4362(17), $\mathrm{Mo}(1)-\mathrm{Cl}(2)$ 2.4159(16), $\mathrm{Mo}(1)-\mathrm{Cl}(3)$ 2.4137(17), $\mathrm{Mo}(1)-\mathrm{N}(1)$ 1.750(5); $\mathrm{Mo}(1)-\mathrm{N}(1)-\mathrm{C}(11)$ 178.4(5), $\mathrm{Cl}(1)-\mathrm{Mo}(1)-\mathrm{Cl}(2)$ 80.04(6).

In the packing (Figure S9), there are a number of weak $\mathrm{C}-\mathrm{H} \cdots \mathrm{Cl}$ interactions. The $\mathrm{F} \cdots \mathrm{I}$ distance at $3.390 \AA$ A suggests weak halogen bonding. The molecules pack in layers with $\mathrm{Cp}^{*} \mathrm{Mo}$ units together and the halogen-bonded imido ligands together.

\subsection{Use of Aniline}

For comparative catalytic studies, we also prepared the complex $\left[\mathrm{Mo}\left(\eta-\mathrm{C}_{5} \mathrm{Me}_{5}\right) \mathrm{Cl}_{2}\left(\mathrm{NC}_{6}\right.\right.$ $\left.\mathrm{H}_{5}\right)$ ] via the use of three equivalents of the parent aniline. As for the other derivatives isolated above, single crystals suitable for an X-ray diffraction study were grown from a saturated solution of acetonitrile. There is one molecule of the complex in the asymmetric unit, which adopts a piano-stool conformation (Figure 11). The $\mathrm{Cp}^{*}$ ligand is disordered over two sets of positions related by a ca. $22^{\circ}$ rotation. The $\mathrm{Mo}(1)$ to $\mathrm{Cp}^{*}$ ring plane distance is 2.013(8) $\AA$ for the major component and 2.058(17) $\AA$ for the minor component. For the major component, all the $\mathrm{Cp}^{*}$ Me groups are bent somewhat away from the ring plane relative to the metal, but $\mathrm{C}(14)$ is notably more displaced away than the other four, presumably due to the proximity of the imido ligand 'below'. The statistics are less reliable for the minor component. The bond lengths $\mathrm{Mo}(1)-\mathrm{C}(11) / \mathrm{C}(11 \mathrm{X}) / \mathrm{C}(7 \mathrm{X})$ are notably longer than the other Mo-C distances, being positioned trans to the imido nitrogen $\mathrm{N}$; the $\tau$ values are $3.2^{\circ}$ and $3.6^{\circ}$ for the major and minor components, respectively. The packing of 8 is shown in Figure S10. 


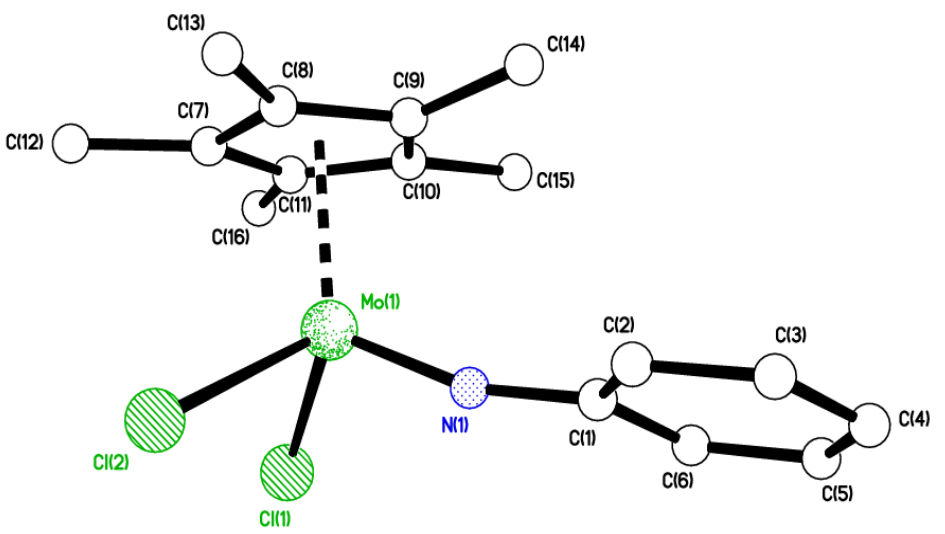

Figure 11. Molecular structure of $\left[\mathrm{Mo}\left(\eta-\mathrm{C}_{5} \mathrm{Me}_{5}\right) \mathrm{Cl}_{2}\left(\mathrm{C}_{6} \mathrm{H}_{5} \mathrm{~N}\right)\right](8)$. Selected bond lengths $(\AA)$ and angles $\left({ }^{\circ}\right)$ : $\mathrm{Mo}(1)-\mathrm{Cl}(1)$ 2.3702(10), $\mathrm{Mo}(1)-\mathrm{Cl}(2)$ 2.3693(11), $\mathrm{Mo}(1)-\mathrm{N}(1)$ 1.735(3); $\mathrm{Mo}(1)-\mathrm{N}(1)-\mathrm{C}(1)$ 165.0(3), $\mathrm{Cl}(1)-\mathrm{Mo}(1)-\mathrm{Cl}(2) 92.16(4)$.

\section{Ring Opening Polymerization (ROP) Studies}

Based on our previous molybdenum ROP studies [20-22], we selected the conditions of $130{ }^{\circ} \mathrm{C}$ with a ratio of $\varepsilon$-CL to complex of 500:1 in the presence of one equivalent of benzyl alcohol over $24 \mathrm{~h}$ under $\mathrm{N}_{2}$. Data for the runs are presented in Table 1, and it can be seen that at ambient temperature, low molecular weight oily products are formed with good control (PDI < 1.25). End group analysis by ${ }^{1} \mathrm{H}$ NMR spectroscopy (e.g., Figure S11 for entry 7 , Table 1) is consistent with the presence of a $\mathrm{BnO}$ end group, which indicates that the polymerization proceeds through a coordination-insertion mechanism. Interestingly, despite the narrow PDI values, MALDI-TOF spectra revealed at least five series of ions corresponding to sodiated PCL. For example, in Figure 12 (using PCL from entry 2, Table 1; for the full spectrum, see Figure S12), for each group of the five species, the end groups, from lowest to highest mass, very likely correspond to $\mathrm{BnO}-/-\mathrm{H}$ (n-1 compared with the rest of the group), no end groups, $\mathrm{H}-/-\mathrm{OH}$ end groups, $\mathrm{MeO}-/-\mathrm{H}$, and the artifact $\mathrm{NaO}-/-\mathrm{H}$. On increasing the temperature from ambient to $70{ }^{\circ} \mathrm{C}$, the molecular weight increased (by more than 6 -fold in the case of 2, entries $5 \mathrm{v} 6$, Table 1), although this was generally at the cost of control. On further increasing the temperature to $130{ }^{\circ} \mathrm{C}$, there was a further increase in polymer molecular weight, together with an increase in the PDI. The presence of a high oxidation state appears beneficial for affording a high molecular weight product given that use of the molybdenum(VI) precursor 7 , afforded the highest molecular weight product, albeit with the worst control (entry 16, Table 1).

However, if the runs were conducted as melts (Table 2), all the systems (except for the use of 2) afforded higher molecular weight products versus runs conducted in solution. Runs employing the amine species 2 (entry 2, Table 2) and 4 (entry 4, Table 2) afforded the lowest molecular weight products. Analysis of the MALDI-TOF spectra again indicated the presence of multiple species, e.g., for the PCL from entry 2 of Table 2, the same five polymer series as identified above were present but in different relative intensities (see Figure 13; for the full spectrum, see Figure S13). 
Table 1. Synthesis of polycaprolactone from using catalysts 1-8 over $24 \mathrm{~h}$ under $\mathrm{N}_{2}{ }^{\mathrm{a}}$.

\begin{tabular}{|c|c|c|c|c|c|c|}
\hline Entry & Cat. & Temp $\left({ }^{\circ} \mathrm{C}\right)$ & Conv. $(\%)^{b}$ & $M_{\mathrm{n}}{ }^{\mathrm{c}}$ & $M_{\text {nCalcd }} \mathrm{d}$ & $\mathrm{PDI}^{\mathrm{e}}$ \\
\hline 1 & 1 & 130 & 99 & 1590 & 56,499 & 1.35 \\
\hline 2 & 1 & 70 & 99 & 4650 & 56,499 & 1.49 \\
\hline 3 & 1 & 15 & 99 & 850 & 56,499 & 1.25 \\
\hline 4 & 2 & 130 & 98.6 & 6840 & 56,271 & 1.33 \\
\hline 5 & 2 & 70 & 99 & 5740 & 56,499 & 1.50 \\
\hline 6 & 2 & 15 & 99 & 890 & 56,499 & 1.21 \\
\hline 7 & 3 & 130 & $>99$ & 16,710 & 56,499 & 1.76 \\
\hline 8 & 3 & 15 & 66.2 & 400 & 37,780 & 1.27 \\
\hline 9 & 4 & 130 & 99 & 1015 & 56,499 & 1.62 \\
\hline 10 & 4 & 70 & 99 & 2490 & 56,499 & 1.19 \\
\hline 11 & 4 & 15 & 99 & 840 & 56,499 & 1.25 \\
\hline 12 & 5 & 130 & 97.4 & 12,300 & 55,586 & 1.76 \\
\hline 13 & 5 & 15 & 97.9 & 900 & 55,872 & 1.22 \\
\hline 14 & 6 & 130 & 98.5 & 5700 & 56,214 & 1.46 \\
\hline 15 & 6 & 15 & 96.3 & 840 & 54,958 & 1.09 \\
\hline 16 & 7 & 130 & 98.7 & 21,470 & 56,328 & 2.10 \\
\hline 17 & 7 & 15 & 96 & 850 & 54,787 & 1.08 \\
\hline 18 & 8 & 130 & 99 & 7740 & 56,499 & 2.12 \\
\hline 19 & 8 & 70 & 99 & 1560 & 56,499 & 1.30 \\
\hline 20 & 8 & 20 & 94.9 & 470 & 54,159 & 1.19 \\
\hline
\end{tabular}

a All conducted with [monomer]:[Cat]: $\mathrm{BnOH}=500: 1: 1 .{ }^{\mathrm{b}}$ Conversion was confirmed by ${ }^{1} \mathrm{H}$ NMR spectroscopy. ${ }^{c}$ Determined by GPC analysis calibrated with polystyrene standards and multiplied by correction factor of 0.56 .

d F.W. $[\mathrm{M}] /[\mathrm{BnOH}])($ conversion $)+\mathrm{BnOH}$. ${ }^{\text {e }}$ Polydispersity index $\left(M_{\mathrm{w}} / M_{\mathrm{n}}\right)$ were determined by GPC.

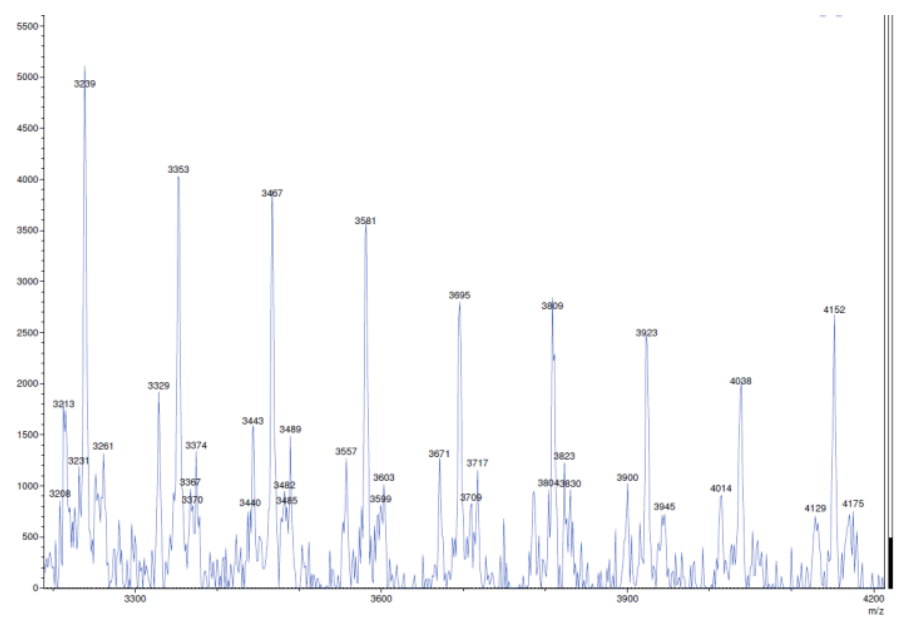

Figure 12. Close up of MALDI-TOF spectrum of PCL (entry 2, Table 1).

Table 2. Synthesis of polycaprolactone from using catalysts $1-8$ as melts $\left(130{ }^{\circ} \mathrm{C}\right)$ under $\mathrm{N}_{2}$ a .

\begin{tabular}{cccccc}
\hline Entry & Cat. & Conv. $(\mathbf{\%}) \mathbf{b}^{\mathbf{b}}$ & $\boldsymbol{M}_{\mathbf{n}}{ }^{\mathbf{c}}$ & $\boldsymbol{M}_{\text {nCalcd }} \mathbf{d}^{\mathbf{d}}$ & PDI $^{\mathbf{e}}$ \\
\hline 1 & $\mathbf{1}$ & 94.7 & 12,490 & 54,045 & 2.41 \\
2 & $\mathbf{2}$ & 97.6 & 3510 & 55,700 & 1.53 \\
3 & $\mathbf{3}$ & $>99$ & 18,290 & 56,499 & 2.05 \\
4 & $\mathbf{4}$ & 97.4 & 5820 & 55,586 & 1.37 \\
5 & $\mathbf{5}$ & 98.5 & 26,780 & 56,214 & 2.00 \\
6 & $\mathbf{6}$ & $>99$ & 19,580 & 56,499 & 1.76 \\
7 & $\mathbf{7}$ & $>99$ & 12,450 & 56,499 & 1.22 \\
8 & $\mathbf{8}$ & $>99$ & 10,990 & 56,499 & 2.35 \\
\hline
\end{tabular}

a All conducted with [monomer]:[Cat]: $\mathrm{BnOH}=500: 1: 1 .{ }^{\mathrm{b}}$ Conversion was confirmed by ${ }^{1} \mathrm{H}$ NMR spectroscopy.

${ }^{c}$ Determined by GPC analysis calibrated with polystyrene standards and multiplied by correction factor of 0.56 .

${ }^{\mathrm{d}}$ F.W. $\left.[\mathrm{M}] /[\mathrm{BnOH}]\right)($ conversion $)+\mathrm{BnOH} .{ }^{\text {e }}$ Polydispersity index $\left(M_{\mathrm{W}} / M_{\mathrm{n}}\right)$ were determined by GPC. 


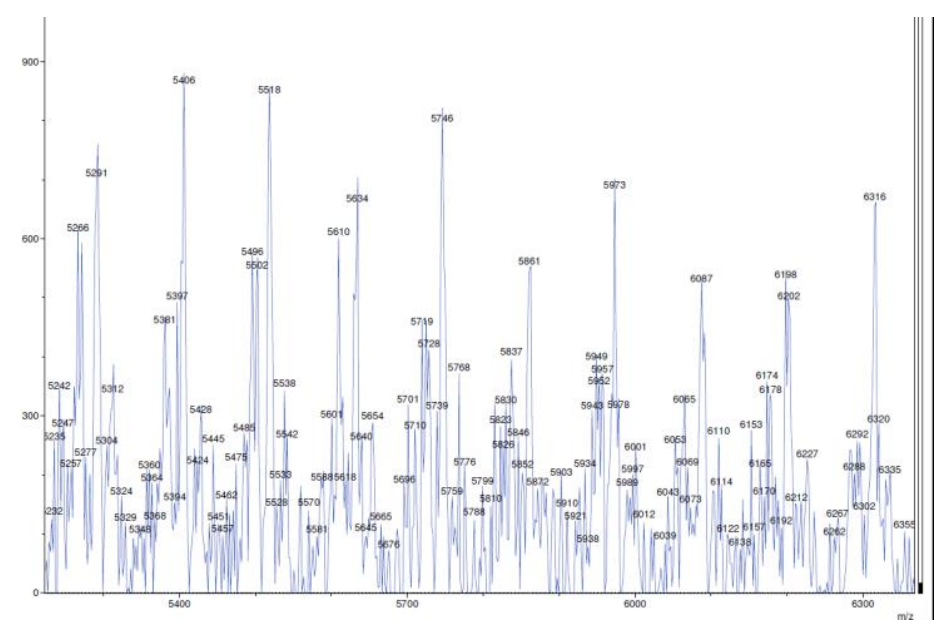

Figure 13. Close up of MALDI-TOF spectrum of PCL (entry 2, Table 2).

Good conversions were also observed on conducting the runs under air at $130{ }^{\circ} \mathrm{C}$ for $24 \mathrm{~h}$ (Table 3). Molecular weights were far higher than those observed under $\mathrm{N}_{2}$ when using 1-5, whilst that for 7 (entry 7, Table 3) was far lower. At ambient temperature under air, the products were low molecular weight oily products (e.g., entry 8, Table 3). In the MALDI-TOF spectra, there is one dominant series corresponding to no end groups, with two minor series likely corresponding to $\mathrm{BnO}-/-\mathrm{H}$ and $\mathrm{H}-/-\mathrm{OH}$ series; the former of these two starts to become more dominant at higher mass (see Figure 14, entry 5, Table 3; for the full spectrum, see Figure S14).

Table 3. Synthesis of polycaprolactone from using catalysts $1-8$ over $24 \mathrm{~h}$ at $130{ }^{\circ} \mathrm{C}$ under air a,b

\begin{tabular}{cccccc}
\hline Entry & Cat. & Conv. $(\mathbf{\%})^{\mathbf{c}}$ & $\boldsymbol{M}_{\mathbf{n}} \mathbf{d}$ & $\boldsymbol{M}_{\mathbf{n C a l c d}} \mathbf{e}^{\mathbf{d}}$ & PDI $^{\mathbf{f}}$ \\
\hline 1 & $\mathbf{1}$ & 89.6 & 17,050 & 51,135 & 2.41 \\
2 & $\mathbf{2}$ & 99 & 18,390 & 56,499 & 2.47 \\
3 & $\mathbf{3}$ & 92.2 & 21,600 & 52,619 & 2.17 \\
4 & $\mathbf{4}$ & 97.8 & 21,040 & 55,814 & 2.45 \\
5 & $\mathbf{5}$ & $>99$ & 20,660 & 56,499 & 2.27 \\
6 & $\mathbf{6}$ & $>99$ & 8640 & 56,499 & 1.71 \\
7 & $\mathbf{7}$ & $>99$ & 7000 & 56,499 & 2.47 \\
8 & $\mathbf{8}^{\mathbf{f}}$ & 99 & 710 & 56,499 & 1.38 \\
9 & $\mathbf{8}$ & $>99$ & 7470 & 56,499 & 1.81
\end{tabular}

a All conducted with [monomer]:[Cat]: $\mathrm{BnOH}=500: 1: 1 .{ }^{\mathrm{b}}$ Conducted at $20^{\circ} \mathrm{C} .{ }^{\mathrm{c}}$ Conversion was confirmed by ${ }^{1} \mathrm{H}$ NMR spectroscopy. ${ }^{\mathrm{d}}$ Determined by GPC analysis calibrated with polystyrene standards and multiplied by correction factor of 0.56 . ${ }^{\mathrm{e}}$ F.W. $\left.[\mathrm{M}] /[\mathrm{BnOH}]\right)($ conversion $)+\mathrm{BnOH} .{ }^{\mathrm{f}}$ Polydispersity index $\left(M_{\mathrm{w}} / M_{\mathrm{n}}\right)$ were determined by GPC.

\section{Kinetics}

Kinetic studies for the imido complexes 1, 3, 5, and 8 (Figure 15), conducted using the ratio 500:1:1 ([CL]:[Cat]:[BnOH]) revealed the rate trend $\mathbf{8}>\mathbf{3}>\mathbf{1}>\mathbf{5}$. This suggests the presence of either a meta- or an ortho-iodo substituent is beneficial to the rate of conversion for the iodo-bearing systems, whilst the best rate was observed for the aniline-derived system. 


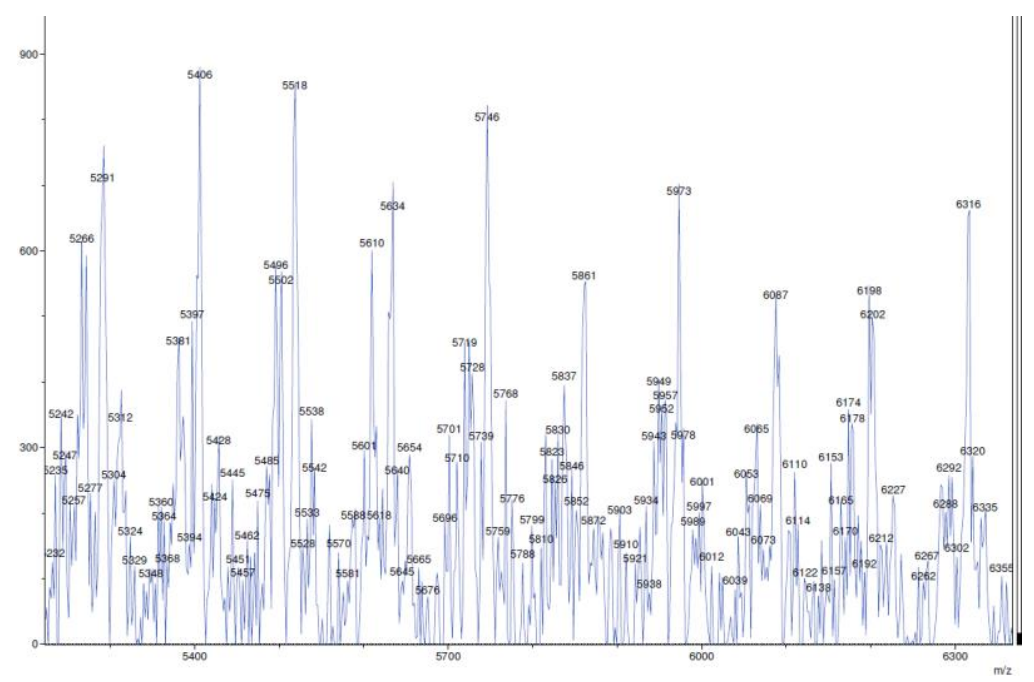

Figure 14. Close up of MALDI-TOF spectrum of PCL (entry 5, Table 3).

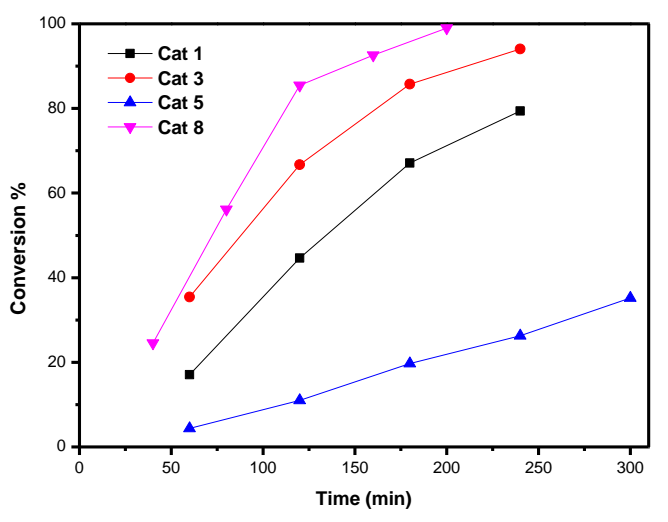

(a)

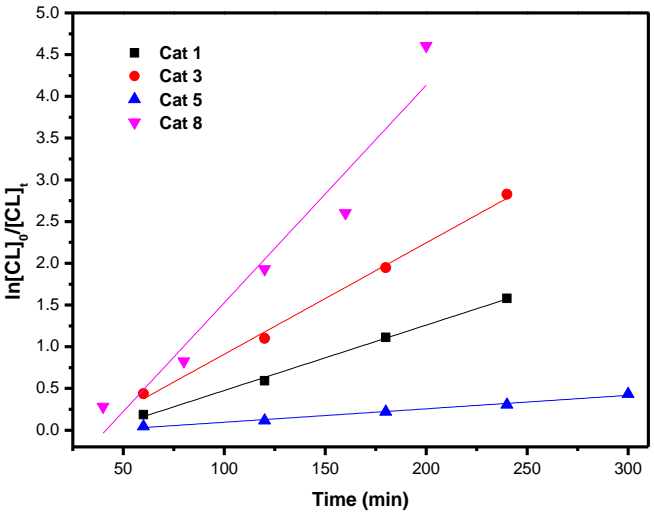

(b)

Figure 15. (a) Relationship between conversion and time for the polymerization of $\varepsilon$-CL by using complexes 1, 3, 5, and 8; (b) Plot of $\ln [\mathrm{CL}]_{0} /[\mathrm{CL}]_{\mathrm{t}}$ vs. time for the polymerization of $\varepsilon$-CL by using complexes $1, \mathbf{3}, \mathbf{5}$, and 8 ; Conditions: $\mathrm{T}=130{ }^{\circ} \mathrm{C}$, $\mathrm{n}_{\text {Monomer }}: \mathrm{n}_{\mathrm{Cat}}: \mathrm{BnOH}=500: 1: 1$.

Comparing the kinetics for complexes 6 and 7 (Figure 16) suggests that a molybde$\operatorname{num}(\mathrm{V})$ centre is beneficial to the rate of conversion versus molybdenum(VI).

For the amine complexes 2 and $\mathbf{4}$, kinetics (Figure 17) revealed, as for the imido complexes, that a meta- rather than a para-iodo group is beneficial for the rate of conversion. Note complex 8 exhibits a slightly better rate than 2 (see Figure S15); prior to screening, sample 2 was dried in vacuo for $>2 \mathrm{~h}$ to remove the acetonitrile of crystallization. 


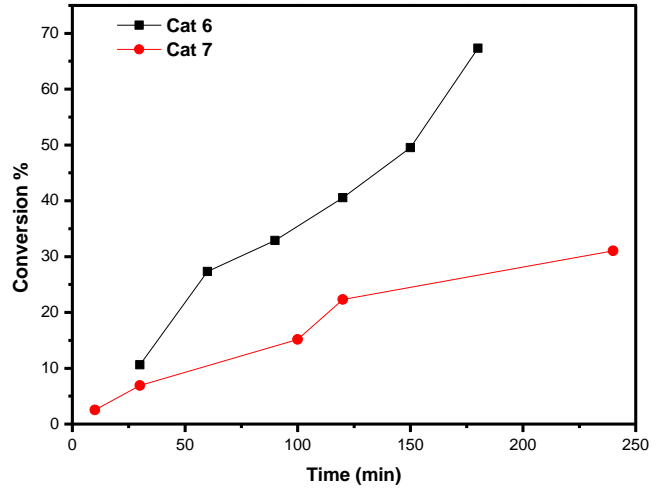

(a)

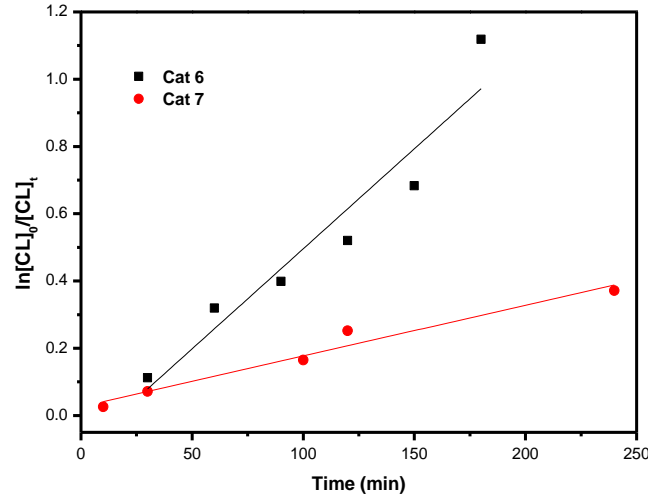

(b)

Figure 16. (a) Relationship between conversion and time for the polymerization of $\varepsilon$-CL by using complexes 6 and 7; (b) Plot of $\ln [\mathrm{CL}]_{0} /[\mathrm{CL}]_{\mathrm{t}}$ vs. time for the polymerization of $\varepsilon$-CL by using complexes 6 and 7; Conditions: $\mathrm{T}=130{ }^{\circ} \mathrm{C}$, $\mathrm{n}_{\text {Monomer }}: \mathrm{n}_{\text {Cat }}: \mathrm{BnOH}=500: 1: 1$.

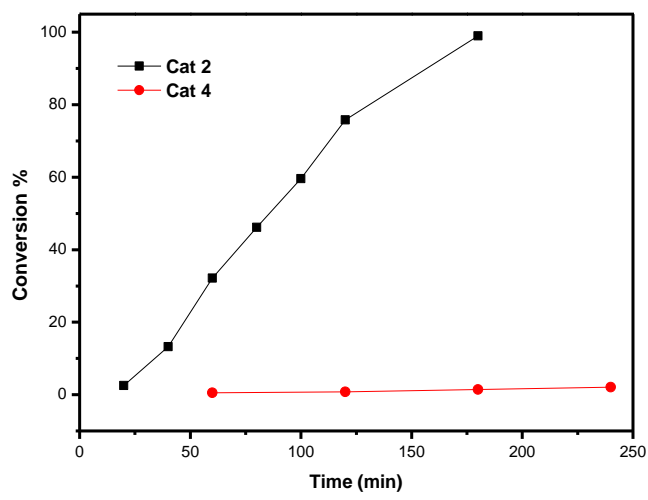

(a)

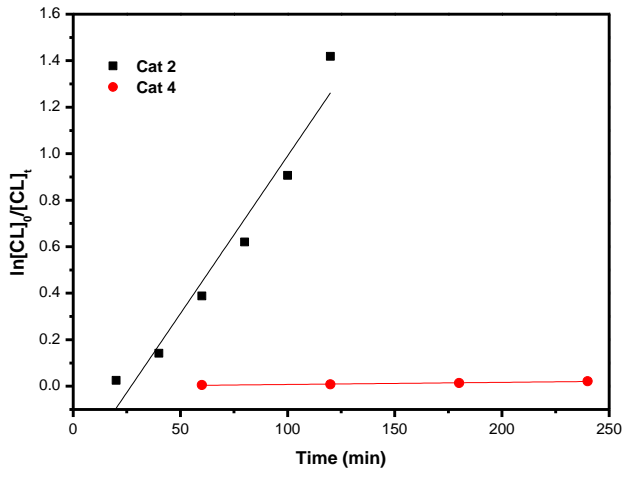

(b)

Figure 17. (a) Relationship between conversion and time for the polymerization of $\varepsilon$-CL by using complex 2 and 4 ; (b) Plot of $\ln [\mathrm{CL}]_{0} /[\mathrm{CL}]_{\mathrm{t}}$ vs. time for the polymerization of $\varepsilon$-CL by using complexes 2 and 4 ; Conditions: $\mathrm{T}=130{ }^{\circ} \mathrm{C}$, $\mathrm{n}_{\text {Monomer }}: \mathrm{n}_{\text {Cat }}: \mathrm{BnOH}=500: 1: 1$.

An overall analysis of the kinetics for the systems herein reveals the rate trend $8>2>$ $3>6 \approx 1>7>5>4$. Thus, the most active catalyst systems amongst the 'functionalized' systems are those bearing a meta iodo substituent, which is more likely influenced by the electronics of the system rather than the sterics. The near linear relationships above imply the polymerizations follow a first-order dependence on the monomer concentration.

\section{Materials and Methods}

\subsection{General}

All manipulations were carried out under an atmosphere of dry nitrogen using conventional Schlenk and cannula techniques or in a conventional nitrogen-filled glove box. Toluene (Aldrich, Dorset, UK) was refluxed over Na-benzophenone/Ketyl (Aldrich, Dorset, UK), acetonitrile (Aldrich, Dorset, UK) was refluxed over calcium hydride (Aldrich, Dorset, UK), whilst benzyl alcohol (Aldrich) was dried over molecular sieves. $\varepsilon$-CL (Aldrich, Dorset, UK) was dried over calcium hydride, and distilled prior to use. The purity of the monomer $\varepsilon$-CL was determined to be $99.6 \%$ (determined by ${ }^{1} \mathrm{H}$ NMR spectroscopy, JEOL ECZ $400 S$ spectrometer, Tokyo, Japan). The anilines 2-iodoaniline (TCI, Oxford, UK), 3iodoaniline (TCI, Oxford, UK), 4-iodoaniline (TCI, Oxford, UK) and 4-fluoro-2-iodoaniline (Fluorochem, Hadfield, UK) were purchased from commercial sources and used directly.

IR spectra (nujol mulls, KBr windows) were recorded on a Nicolet Avatar 360 FT IR spectrometer (Thermo Nicolet Corporation, Madison, WI, USA); ${ }^{1} \mathrm{H}$ NMR spectra 
were recorded at 400.2 $\mathrm{MHz}$ at room temperature on a on a JEOL ECZ 400S spectrometer (JEOL Ltd., Tokyo, Japan). The ${ }^{1} \mathrm{H}$ NMR spectra were calibrated against the residual protio-impurity of the deuterated solvent; chemical shifts are given in ppm $(\delta)$. Elemental analyses were performed by the elemental analysis service in the Department of Chemistry at the University of Hull, OEA Labs Ltd. (Devon, UK), or London Metropolitan University. The precursor $\left[\mathrm{Mo}\left(\eta-\mathrm{C}_{5} \mathrm{Me}_{5}\right) \mathrm{Cl}_{4}\right]$ was prepared by the literature method [6]. All other chemicals were purchased from Sigma Aldrich or TCI UK.

MALDI-TOF mass spectra (Wyatt Analytical Ltd., Colwyn Bay, UK) were acquired on a Bruker Autoflex Speed MALDI-TOF spectrometer, in both positive-linear (LP/-1) and reflectron (RP/-3) modes and processed with Bruker PolyTools and Strohalm mMass (v5.5.0) software. Molecular weights were calculated from the experimental traces using the OmniSEC 467 (Thermo Nicolet Corporation, Madison, WI, USA).

The mass spectra of the complexes 1-8 were run on a Bruker Maxis Impact HD Mass spectrometer at the University of Hull in ESI positive mode, or at the National Mass Spectrometry Facility at Swansea (UK), using an atmospheric solids analysis probe (ASAP).

\subsection{Synthesis of $\left[\mathrm{Mo}\left(\eta-\mathrm{C}_{5} \mathrm{Me}_{5}\right) \mathrm{Cl}_{2}\left(2-\mathrm{IC}_{6} \mathrm{H}_{4} \mathrm{~N}\right)\right](\mathbf{1})$}

To $\left[\mathrm{Mo}\left(\eta-\mathrm{C}_{5} \mathrm{Me}_{5}\right) \mathrm{Cl}_{4}\right](1.00 \mathrm{~g}, 2.68 \mathrm{mmol})$ and $2-\mathrm{IC}_{6} \mathrm{H}_{4} \mathrm{NH}_{2}(1.76 \mathrm{~g}, 8.04 \mathrm{mmol})$ in a Schlenk flask was added toluene $(20 \mathrm{~mL})$. The system was refluxed for $12 \mathrm{~h}$, and on cooling, volatiles were removed. The residue was extracted into $\mathrm{MeCN}(40 \mathrm{~mL})$ and on standing for $24 \mathrm{~h}$ at $0{ }^{\circ} \mathrm{C}$ afforded the complex 1 as dark crystals. Yield $1.06 \mathrm{~g}, 76 \% . \mathrm{C}_{16} \mathrm{H}_{19} \mathrm{Cl}_{2} \mathrm{NIMo}$ requires C 37.02, H 3.69, N 2.70\%. Found C 37.02, H 4.09, N 3.71\%. IR: 1631w, 1564w, 1301s, 1261s, 1198w, 1156m, 1140w, 1092m, 1044m, 1016s, 967m, 948w, 919w, 892w, 844w, 801m, 765s, 722s, 690w, 645w, 635w, 6166w, 565m. Mass spec (ASAP, solid): 483 (M+Cl).

\subsection{Synthesis of $\left[\mathrm{Mo}\left(\eta-\mathrm{C}_{5} \mathrm{Me}_{5}\right) \mathrm{Cl}_{4}\left(3-\mathrm{IC}_{6} \mathrm{H}_{4} \mathrm{NH}_{2}\right)\right] \cdot \mathrm{MeCN}(\mathbf{2} \cdot \mathrm{MeCN})$}

As for 1, but using [ $\left.\mathrm{Mo}\left(\eta-\mathrm{C}_{5} \mathrm{Me}_{5}\right) \mathrm{Cl}_{4}\right](1.00 \mathrm{~g}, 2.68 \mathrm{mmol})$ and $3-\mathrm{IC}_{6} \mathrm{H}_{4} \mathrm{NH}_{2}(0.32 \mathrm{~mL}$, $2.7 \mathrm{mmol}$ ) which, under prolonged standing at $0{ }^{\circ} \mathrm{C}$ afforded dark red crystals of $2 \cdot \mathrm{MeCN}$. Yield $0.97 \mathrm{~g}, 57 \%$. $\mathrm{C}_{16} \mathrm{H}_{21} \mathrm{Cl}_{4} \mathrm{NIMo} \cdot\left(\mathrm{C}_{2} \mathrm{H}_{3} \mathrm{~N}\right.$ ) requires (sample dried in vacuo for $2 \mathrm{~h}$, MeCN) C 32.46, H 3.58, N 2.37\% Found C 33.28, H 3.85, N 2.31\%. IR: 3415w, 3328w, 2314w, 2289w, 2250w, 1702w, 1644w, 1570w, 1552w, 1306m, 1260s, 1168m, 1156m, 1094s, 1062s, 1020s, 987m, 932w, 911w, 879w, 847w, 801s, 782m, 722s, 673w, 655w. Mass spec (ASAP, solid): 521 ( $\left.\mathrm{M}^{+}-\mathrm{MeCN}-2 \mathrm{Cl}\right), 486\left(\mathrm{M}^{+}-\mathrm{MeCN}-3 \mathrm{Cl}\right)$.

\subsection{Synthesis of $\left[\mathrm{Mo}\left(\eta-\mathrm{C}_{5} \mathrm{Me}_{5}\right) \mathrm{Cl}_{2}\left(3-\mathrm{IC}_{6} \mathrm{H}_{4} \mathrm{~N}\right)\right]$ (3)}

As for 2 but using [Mo( $\left.\left(\eta-\mathrm{C}_{5} \mathrm{Me}_{5}\right) \mathrm{Cl}_{4}\right](1.00 \mathrm{~g}, 2.68 \mathrm{mmol})$ and $3-\mathrm{IC}_{6} \mathrm{H}_{4} \mathrm{NH}_{2}(0.97 \mathrm{~mL}$, $8.1 \mathrm{mmol}$ ) which, under prolonged standing at $0{ }^{\circ} \mathrm{C}$ afforded dark red crystals of 3 . Yield $0.95 \mathrm{~g}, 68 \%$. $\mathrm{C}_{16} \mathrm{H}_{19} \mathrm{Cl}_{2} \mathrm{NIMo}$ requires C 37.02, H 3.69, N 2.70\%. Found C 36.81, H 4.03, N 2.65\%. IR: 1583w, 1557w, 1414m, 1260s, 1094s, 1020s, 908w, 865m, 800s, 733w, 697w, 673w, 662w, 571w, 550w, 526w, 507w, 466w. M.S. (ESI, positive): $448\left(\mathrm{M}^{+}-2 \mathrm{Cl}\right)$.

\subsection{Synthesis of $\left[\mathrm{Mo}\left(\eta-\mathrm{C}_{5} \mathrm{Me}_{5}\right) \mathrm{Cl}_{4}\left(4-\mathrm{IC}_{6} \mathrm{H}_{4} \mathrm{NH}_{2}\right)\right](4)$}

As for 1 but using $\left[\mathrm{Mo}\left(\eta-\mathrm{C}_{5} \mathrm{Me}_{5}\right) \mathrm{Cl}_{4}\right](1.00 \mathrm{~g}, 2.68 \mathrm{mmol})$ and $4-\mathrm{IC}_{6} \mathrm{H}_{4} \mathrm{NH}_{2}(0.59 \mathrm{~g}$ $2.7 \mathrm{mmol}$ ) which, under prolonged standing at $0{ }^{\circ} \mathrm{C}$ afforded dark red crystals of 4 . Yield $0.72 \mathrm{~g}$, 45\%. $\mathrm{C}_{16} \mathrm{H}_{21} \mathrm{Cl}_{4} \mathrm{NIMo} \cdot \frac{1}{2} \mathrm{MeCN}$ requires $\mathrm{C} 33.33, \mathrm{H} 3.70, \mathrm{~N} 3.43 \%$. Found C 33.33, $\mathrm{H}$ 3.51, N 3.40\%. IR: 3421w, 3332w, 2310w, 2288w, 1641m, 1609m, 1558m, 1401s, 1312m, 1260s, $1197 \mathrm{~m}, 1170 \mathrm{~m}, 1094 \mathrm{~s}, 1058 \mathrm{~s}, 1020 \mathrm{~s}, 1011 \mathrm{~s}, 987 \mathrm{~s}, 933 \mathrm{w}, 913 \mathrm{~m}, 879 \mathrm{w}, 846 \mathrm{~m}, 805 \mathrm{~s}, 722 \mathrm{~m}, 687 \mathrm{w}$, 660w. Mass spec (ASAP, solid): $521\left(\mathrm{M}^{+}-2 \mathrm{Cl}\right), 486\left(\mathrm{M}^{+}-3 \mathrm{Cl}\right)$.

\subsection{Synthesis of $\left[\mathrm{Mo}\left(\eta-\mathrm{C}_{5} \mathrm{Me}_{5}\right) \mathrm{Cl}_{2}\left(4-\mathrm{IC}_{6} \mathrm{H}_{4} \mathrm{~N}\right)\right](\mathbf{5})$}

As for 1 but using $\left[\mathrm{Mo}\left(\eta-\mathrm{C}_{5} \mathrm{Me}_{5}\right) \mathrm{Cl}_{4}\right](1.00 \mathrm{~g}, 2.68 \mathrm{mmol})$ and $4-\mathrm{IC}_{6} \mathrm{H}_{4} \mathrm{NH}_{2}(1.76 \mathrm{~g}$, $8.04 \mathrm{mmol}$ ) affording 5 as dark crystals. Yield: $0.83 \mathrm{~g}, 60 \% . \mathrm{C}_{16} \mathrm{H}_{19} \mathrm{Cl}_{2} \mathrm{NIMo}$ requires $\mathrm{C}$ 37.02, H 3.69, N 2.70\%. Found C 36.94, H 4.24, N 2.71\%. IR: 1558w, 1312s, 1290w, 1261s, 
$1208 \mathrm{w}, 1167 \mathrm{w}, 1153 \mathrm{w}, 1110 \mathrm{~m}, 1093 \mathrm{~s}, 1051 \mathrm{~m}, 1022 \mathrm{~s}, 998 \mathrm{~s}, 986 \mathrm{~m}, 893 \mathrm{w}, 838 \mathrm{~s}, 809 \mathrm{~s}, 800 \mathrm{~s}, 723 \mathrm{~m}$, 669m, 633w, 614w, 536m, 516s. M.S. (ESI, positive): $520\left(\mathrm{MH}^{+}\right), 449\left(\mathrm{M}^{+}-2 \mathrm{Cl}\right)$.

\subsection{Synthesis of $\left[\mathrm{Mo}\left(\eta-\mathrm{C}_{5} \mathrm{Me}_{5}\right) \mathrm{Cl}_{2}\left(2-\mathrm{I}, 4-\mathrm{FC}_{6} \mathrm{H}_{3} \mathrm{~N}\right)\right] \cdot \mathrm{MeCN}(\mathbf{6} \cdot \mathrm{MeCN})$}

To $\left[\mathrm{Mo}\left(\mathrm{\eta}-\mathrm{C}_{5} \mathrm{Me}_{5}\right) \mathrm{Cl}_{4}\right](1.12 \mathrm{~g}, 3.00 \mathrm{mmol})$ and $2-\mathrm{I}, 4-\mathrm{FC}_{6} \mathrm{H}_{3} \mathrm{NH}_{2}(0.36 \mathrm{~mL}, 3.0 \mathrm{mmol})$ in a Schlenk flask was added toluene $(20 \mathrm{~mL})$ and triethylamine $(0.86 \mathrm{~mL}, 6.2 \mathrm{mmol})$. The system was stirred for $12 \mathrm{~h}$, and then the volatiles were removed. The residue was extracted into $\mathrm{MeCN}(40 \mathrm{~mL})$ and on standing for $24 \mathrm{~h}$ at ambient temperature, the complex $6 \cdot \mathrm{MeCN}$ formed as dark orange crystals. Yield $1.06 \mathrm{~g}, 61 \%$. $\mathrm{C}_{16} \mathrm{H}_{18} \mathrm{Cl}_{2}$ FNIMo requires $\mathrm{C} 35.75, \mathrm{H}$ 3.38, N 2.61\%. Found C 35.50, H 3.67, N 2.67\%. IR: 1573m, 1561m, 1309m, 1283w, 1259s, $1245 \mathrm{~m}, 1199 \mathrm{~s}, 1157 \mathrm{w}, 1109 \mathrm{~m}, 1095 \mathrm{~m}, 1032 \mathrm{~s}, 1022 \mathrm{~s}, 985 \mathrm{w}, 950 \mathrm{w}, 891 \mathrm{w}, 869 \mathrm{~s}, 855 \mathrm{~m}, 821 \mathrm{~s}, 802 \mathrm{~s}$, $722 \mathrm{~m}, 663 \mathrm{w}, 623 \mathrm{w}, 589 \mathrm{w}, 576 \mathrm{w}, 552 \mathrm{w}, 467 \mathrm{w}, 451 \mathrm{~m}$. M.S. (ESI, positive): $543\left(\mathrm{M}^{+}-\mathrm{Cl}\right), 537$ $\left(\mathrm{M}^{+}-\mathrm{MeCN}\right)$.

\subsection{Synthesis of $\left[\mathrm{Mo}\left(\eta-\mathrm{C}_{5} \mathrm{Me}_{5}\right) \mathrm{Cl}_{3}\left(2-\mathrm{I}, 4-\mathrm{FC}_{6} \mathrm{H}_{3} \mathrm{~N}\right)\right](7)$}

As for 1 but using $\left[\mathrm{Mo}\left(\mathrm{\eta}-\mathrm{C}_{5} \mathrm{Me}_{5}\right) \mathrm{Cl}_{4}\right](1.00 \mathrm{~g}, 2.68 \mathrm{mmol})$ and 2-I,4- $-\mathrm{FC}_{6} \mathrm{H}_{3} \mathrm{NH}_{2}(0.96 \mathrm{~mL}$, $8.1 \mathrm{mmol}$ ) affording 7 as yellow plate-like crystals. Yield $0.83 \mathrm{~g}, 54 \% . \mathrm{C}_{16} \mathrm{H}_{18} \mathrm{Cl}_{3} \mathrm{FNIMo}$ requires C 33.57, H 3.17, N 2.45\%. Found C 34.21, H 3.48, N 3.23\%. IR: 1745w, 1606w, 1595w, $1574 \mathrm{w}, 1543 \mathrm{w}, 1299 \mathrm{~m}, 1260 \mathrm{~s}, 1240 \mathrm{~m}, 1198 \mathrm{~m}, 1184 \mathrm{~s}, 1158 \mathrm{~m}, 1096 \mathrm{~s}, 1022 \mathrm{~s}, 985 \mathrm{w}, 932 \mathrm{w}, 910 \mathrm{w}$, 879m, 864m, 801s, 753w, 722m, 663w. ${ }^{1} \mathrm{H}$ NMR $\left(\mathrm{CDCl}_{3}, 400 \mathrm{MHz}\right), 8: 7.66(\mathrm{~m}, 1 \mathrm{H}$, aryl H), $7.61(\mathrm{~m}, 1 \mathrm{H}, \operatorname{aryl} H), 7.14(\mathrm{~m}, 1 \mathrm{H}, \operatorname{aryl} H), 2.27\left(\mathrm{~s}, 15 \mathrm{H}, \mathrm{C}_{5} M e_{5}\right)$. M.S. (ESI, positive): 502 $\left(\mathrm{M}^{+}-2 \mathrm{Cl}\right)$.

\subsection{Synthesis of $\left[\mathrm{Mo}\left(\eta-\mathrm{C}_{5} \mathrm{Me}_{5}\right) \mathrm{Cl}_{2}\left(\mathrm{C}_{6} \mathrm{H}_{5} \mathrm{~N}\right)\right]$ (8)}

As for 1 but using $\left[\mathrm{Mo}\left(\eta-\mathrm{C}_{5} \mathrm{Me}_{5}\right) \mathrm{Cl}_{4}\right](1.00 \mathrm{~g}, 2.68 \mathrm{mmol})$ and $\mathrm{C}_{6} \mathrm{H}_{4} \mathrm{NH}_{2}(0.75 \mathrm{~g}$, $8.1 \mathrm{mmol}$ ) affording 8 as pale brown crystals. Yield: $0.84 \mathrm{~g}, 80 \% . \mathrm{C}_{16} \mathrm{H}_{20} \mathrm{Cl}_{2} \mathrm{NMo}$ requires C 48.87, H 5.13, N 3.56\%. Found C 49.71, H 5.12, N 4.16\%. IR: 1565w, 1303m, 1260s, 1200w, $1153 \mathrm{w}, 1095 \mathrm{~m}, 1068 \mathrm{~m}, 1021 \mathrm{~s}, 981 \mathrm{~m}, 920 \mathrm{w}, 881 \mathrm{w}, 801 \mathrm{~m}, 775 \mathrm{~s}, 740 \mathrm{~m}, 723 \mathrm{~m}, 691 \mathrm{~m}, 617 \mathrm{w}, 548 \mathrm{w}$, 506w, 473w. M.S. (ESI, positive): $394\left(\mathrm{MH}^{+}\right), 357\left(\mathrm{M}^{+}-\mathrm{Cl}\right)$.

\subsection{ROP of $\varepsilon$-Caprolactone ( $\varepsilon$-CL)}

All polymerizations were carried out in Schlenk tubes under nitrogen atmosphere unless otherwise stated. $\varepsilon$-CL was polymerized using complexes 1-8 in the presence of $\mathrm{BnOH}(0.1 \mathrm{M}$ in toluene) as a co-initiator. Complexes were weighed out in the glove box and then initiator and monomer were added to the flask successively via syringe. The molar ratio of monomer/catalyst/BnOH $([\mathrm{CL}] /[\mathrm{Cat}] /[\mathrm{BnOH}])$ used was 500:1:1. The reaction mixture was then placed into an oil bath, preheated to the required temperature. The reaction was quenched by the addition of an excess of glacial acetic acid $(0.2 \mathrm{~mL})$, then the reaction solution was poured into cold methanol $(20 \mathrm{~mL})$. The reaction conversion was monitored by ${ }^{1} \mathrm{H}$ NMR $\left(400 \mathrm{MHz}, \mathrm{CDCl}_{3}, 25^{\circ} \mathrm{C}\right)$ spectroscopic studies. The resulting polymer was washed several times with methanol, collected on filter paper and then dried under vacuum to constant weight at $40^{\circ} \mathrm{C}$. GPC (in THF) were used to determine molecular weights $\left(M_{\mathrm{n}}\right.$ and PDI) of the polymer products.

\subsection{Polymerization Kinetics}

Kinetic experiments were carried out following the previous polymerization method. At regular time intervals, $0.05 \mathrm{~mL}$ aliquots were removed, quenched with wet $\mathrm{CDCl}_{3}$ $(1 \mathrm{~mL})$, and analysed by ${ }^{1} \mathrm{H}$ NMR spectroscopy.

\subsection{Polymer Samples Preparation for MALDI-TOF}

All samples were dissolved in THF, as was the matrix. Data was acquired using a dithranol matrix and NaTFA additive, where the matrix, sample, and additive solutions were mixed together in a 5:1:0.1 ratio. Then, $0.5 \mu \mathrm{L}$ of the mixture solution was spotted onto the MALDI target and left to air-dry prior to analysis. 


\subsection{Crystal Structure Determinations}

In all cases, crystals suitable for an $X$-ray diffraction study were grown from a saturated $\mathrm{MeCN}$ solution at $0{ }^{\circ} \mathrm{C}$ or ambient temperature. Compounds 3 and $3 \mathbf{I}$ co-crystallized from the same vial. All (except 1) single crystal X-ray diffraction data were collected at the UK National Crystallography service using Rigaku Oxford Diffraction ultra-high intensity instruments employing modern areas detectors. For $\mathbf{1}$ diffraction data were collected using silicon 111-monochromated synchrotron radiation at Daresbury Laboratory Station 9.8. In all cases, standard procedures were employed for integration and processing of data.

Complex 2 was refined as a two-component non-merohedral twin with $180^{\circ}$ rotation about direct and reciprocal axes 001 with the major:minor component ratio: 56.2:43.8(2)\%. For 7 , there was some evidence of unresolved twinning from some largish residual electron density peaks and $F_{\mathrm{obs}}>F_{\text {calc }}$ for many reflections.

Crystal structures were solved using dual space methods implemented within SHELXT [28]. The completion of these structures was achieved by performing least squares refinement against all unique $F^{2}$ values using SHELXL-2018 [29]. Table 4 contains the crystallographic data for 1-8, 2-I NH${ }_{3} \mathrm{Cl}$ and 3-I NH${ }_{3} \mathrm{Cl}$. CCDC 2122492-2122501 contain the supplementary crystallographic data for this paper. These data can be obtained free of charge from The Cambridge Crystallographic Data Centre via www.ccdc.cam.ac.uk/structures (accessed on 6 December 2021).

Table 4. X-ray crystallographic data for 1-8, 2-I NH${ }_{3} \mathrm{Cl}$ and 3- $\mathrm{NH}_{3} \mathrm{Cl}$.

\begin{tabular}{|c|c|c|c|c|}
\hline Compound & 1 & $2 \cdot \mathrm{MeCN}$ & 3 & 4 \\
\hline Formula & $\mathrm{C}_{16} \mathrm{H}_{19} \mathrm{Cl}_{2} \mathrm{NIMo}$ & $\mathrm{C}_{16} \mathrm{H}_{21} \mathrm{Cl}_{4} \mathrm{NIMo} \cdot\left(\mathrm{C}_{2} \mathrm{H}_{3} \mathrm{~N}\right)$ & $\mathrm{C}_{16} \mathrm{H}_{19} \mathrm{Cl}_{2} \mathrm{NIMo}$ & $\mathrm{C}_{16} \mathrm{H}_{21} \mathrm{Cl}_{4} \mathrm{NIMo}$ \\
\hline Formula weight & 519.06 & 633.03 & 519.06 & 591.98 \\
\hline Crystal system & Monoclinic & Monoclinic & Monoclinic & Monoclinic \\
\hline Space group & $P 2_{1} / c$ & $P 2_{1} / c$ & $P 2_{1} / c$ & $P 2_{1} / c$ \\
\hline$a(\AA)$ & $13.959(7)$ & $8.6986(4)$ & $14.2972(2)$ & $11.8409(3)$ \\
\hline$b(\AA)$ & $7.926(4)$ & $22.7727(7)$ & $17.0160(2)$ & $9.8584(2)$ \\
\hline$c(\AA)$ & $16.248(8)$ & $11.3268(10)$ & $7.60500(12)$ & $17.9445(4)$ \\
\hline$\alpha\left(^{\circ}\right)$ & 90 & 90 & 90 & 90 \\
\hline$\beta\left(^{\circ}\right)$ & $97.953(10)$ & $92.068(5)$ & $101.7956(15)$ & $105.356(3)$ \\
\hline$\gamma\left({ }^{\circ}\right)$ & 90 & 90 & 90 & 90 \\
\hline$V\left(\AA^{3}\right)$ & $1780.4(15)$ & $2242.3(2)$ & $1811.08(4)$ & 2019.92(8) \\
\hline Z & 4 & 4 & 4 & 4 \\
\hline Temperature (K) & $120(2)$ & $100(2)$ & $100(2)$ & $100(2)$ \\
\hline Wavelength $(\AA)$ & 0.6903 & 0.71073 & 0.71073 & 0.71073 \\
\hline Calculated density (g.cm $\left.{ }^{-3}\right)$ & 1.936 & 1.875 & 1.904 & 1.947 \\
\hline Absorption coefficient $\left(\mathrm{mm}^{-1}\right)$ & 2.52 & 2.44 & 2.72 & 2.71 \\
\hline Transmission factors (min./max.) & $0.770,0.947$ & $0.256,1.000$ & $0.595,1.000$ & $0.326,1.000$ \\
\hline Crystal size $\left(\mathrm{mm}^{3}\right)$ & $0.10 \times 0.05 \times 0.02$ & $0.22 \times 0.09 \times 0.04$ & $0.20 \times 0.18 \times 0.04$ & $0.12 \times 0.04 \times 0.02$ \\
\hline$\theta(\max )\left(^{\circ}\right)$ & 25.0 & 27.6 & 28.7 & 27.5 \\
\hline Reflections measured & 7905 & 17958 & 36812 & 19181 \\
\hline Unique reflections & 3172 & 8457 & 4670 & 4624 \\
\hline$R_{\text {int }}$ & 0.032 & 0.163 & 0.034 & 0.063 \\
\hline Reflections with $F^{2}>2 \sigma\left(F^{2}\right)$ & 2863 & 7052 & 4519 & 3231 \\
\hline Number of parameters & 195 & 242 & 196 & 221 \\
\hline$R_{1}\left[F^{2}>2 \sigma\left(F^{2}\right)\right]$ & 0.048 & 0.094 & 0.016 & 0.036 \\
\hline$w R 2$ (all data) & 0.135 & 0.226 & 0.040 & 0.089 \\
\hline GOOF, $S$ & 1.06 & 1.10 & 1.13 & 1.02 \\
\hline Largest difference peak and hole $\left(\mathrm{e} \AA^{-3}\right)$ & 3.08 and -1.44 & 3.13 and -1.84 & 0.55 and -0.40 & 0.81 and -0.92 \\
\hline
\end{tabular}


Table 4. Cont.

\begin{tabular}{|c|c|c|c|c|}
\hline Compound & 5 & $6 \mathrm{MeCN}$ & 7 & 8 \\
\hline Formula & $\mathrm{C}_{16} \mathrm{H}_{19} \mathrm{Cl}_{2}$ NIMo & $\mathrm{C}_{18} \mathrm{H}_{21} \mathrm{C}_{12} \mathrm{FN}_{2} \mathrm{IMo}$ & $\mathrm{C}_{16} \mathrm{H}_{18} \mathrm{Cl}_{3}$ FNIMo & $\mathrm{C}_{16} \mathrm{H}_{20} \mathrm{Cl}_{2} \mathrm{NMo}$ \\
\hline Formula weight & 519.06 & 578.11 & 572.50 & 393.17 \\
\hline Crystal system & Orthorhombic & Monoclinic & Orthorhombic & Orthorhombic \\
\hline Space group & $\mathrm{Pca}_{1}$ & $I 2 / \mathrm{a}$ & $F d d 2$ & $\mathrm{Pbca}$ \\
\hline$a(\AA)$ & $15.3004(5)$ & $14.45516(19)$ & $14.6309(3)$ & $12.93812(8)$ \\
\hline$b(\AA)$ & $7.28895(19)$ & $8.64656(9)$ & 63.6134(13) & 14.34123(9) \\
\hline$c(\AA)$ & $16.7395(4)$ & $33.2386(4)$ & $8.14550(17)$ & $17.82290(11)$ \\
\hline$\alpha\left({ }^{\circ}\right)$ & 90 & 90 & 90 & 90 \\
\hline$\beta\left(^{\circ}\right)$ & 90 & $96.0961(12)$ & 90 & 90 \\
\hline$\gamma\left({ }^{\circ}\right)$ & 90 & 90 & 90 & 90 \\
\hline$V\left(\AA^{3}\right)$ & 1866.85(9) & 4130.91(9) & $7581.2(3)$ & $3307.01(4)$ \\
\hline Z & 4 & 8 & 16 & 8 \\
\hline Temperature (K) & $100(2)$ & $100(2)$ & $100(2)$ & $100(2)$ \\
\hline Wavelength $(\AA)$ & 0.71073 & 0.71073 & 0.71073 & 1.54178 \\
\hline Calculated density $\left(\mathrm{g} \cdot \mathrm{cm}^{-3}\right)$ & 1.847 & 1.859 & 2.006 & 1.579 \\
\hline Absorption coefficient $\left(\mathrm{mm}^{-1}\right)$ & 2.64 & 2.40 & 2.75 & 9.36 \\
\hline Transmission factors (min./max.) & $0.722,1.000$ & $0.775,1.000$ & $0.960,1.000$ & $0.537,0.893$ \\
\hline Crystal size $\left(\mathrm{mm}^{3}\right)$ & $0.20 \times 0.18 \times 0.12$ & $0.24 \times 0.16 \times 0.08$ & $0.24 \times 0.18 \times 0.03$ & $0.09 \times 0.04 \times 0.02$ \\
\hline$\theta(\max )\left(^{\circ}\right)$ & 28.7 & 28.7 & 33.2 & 70.5 \\
\hline Reflections measured & 19105 & 36899 & 59080 & 113441 \\
\hline Unique reflections & 4744 & 5345 & 6772 & 3153 \\
\hline$R_{\text {int }}$ & 0.037 & 0.016 & 0.061 & 0.043 \\
\hline Reflections with $F^{2}>2 \sigma\left(F^{2}\right)$ & 4704 & 5113 & 6613 & 3095 \\
\hline Number of parameters & 196 & 232 & 213 & 273 \\
\hline$R_{1}\left[F^{2}>2 \sigma\left(F^{2}\right)\right]$ & 0.024 & 0.016 & 0.042 & 0.038 \\
\hline$w R 2$ (all data) & 0.062 & 0.037 & 0.095 & 0.084 \\
\hline GOOF, $S$ & 1.06 & 1.10 & 1.12 & 1.32 \\
\hline Largest difference peak and hole $\left(\mathrm{e} \AA^{-3}\right)$ & 1.08 and -0.96 & 0.47 and -0.45 & 2.69 and -1.49 & 0.46 and -0.81 \\
\hline Compound & \multicolumn{2}{|c|}{$2-\mathrm{I} \mathrm{NH}{ }_{3} \mathrm{Cl}$} & \multicolumn{2}{|c|}{$3-\mathrm{I} \mathrm{NH}_{3} \mathrm{Cl}$} \\
\hline Formula & \multicolumn{2}{|c|}{$\mathrm{C}_{6} \mathrm{H}_{7} \mathrm{NI} \cdot \mathrm{Cl}$} & \multicolumn{2}{|c|}{$\mathrm{C}_{6} \mathrm{H}_{7} \mathrm{NI} \cdot \mathrm{Cl}$} \\
\hline Formula weight & \multicolumn{2}{|c|}{255.48} & \multicolumn{2}{|c|}{255.48} \\
\hline Crystal system & \multicolumn{2}{|c|}{ Monoclinic } & \multicolumn{2}{|c|}{ Monoclinic } \\
\hline Space group & \multicolumn{2}{|c|}{$P 2_{1} / c$} & \multicolumn{2}{|c|}{$P 2_{1} / n$} \\
\hline$a(\AA)$ & \multicolumn{2}{|c|}{$9.24697(19)$} & \multicolumn{2}{|c|}{$4.51643(17)$} \\
\hline$b(\AA)$ & \multicolumn{2}{|c|}{$9.29797(18)$} & \multicolumn{2}{|c|}{$5.99872(17)$} \\
\hline$c(\AA)$ & \multicolumn{2}{|c|}{$9.3626(2)$} & \multicolumn{2}{|c|}{$30.1104(11)$} \\
\hline$\alpha\left({ }^{\prime}\right)$ & \multicolumn{2}{|c|}{90} & \multicolumn{2}{|c|}{90} \\
\hline$\beta\left(^{\circ}\right)$ & & & & \\
\hline$\gamma\left({ }^{\circ}\right)$ & & & & \\
\hline$V\left(\AA^{3}\right)$ & & & & \\
\hline $\mathrm{Z}$ & & & & \\
\hline Temperature (K) & & & & \\
\hline Wavelength $(\AA)$ & & & & \\
\hline Calculated density $\left(\mathrm{g} \cdot \mathrm{cm}^{-3}\right)$ & & & & \\
\hline Absorption coefficient $\left(\mathrm{mm}^{-1}\right)$ & & & & \\
\hline Transmission factors (min./max.) & & .000 & & \\
\hline Crystal size $\left(\mathrm{mm}^{3}\right)$ & $0.18 \times$ & $\times 0.09$ & $0.16 \times$ & $\times 0.01$ \\
\hline$\theta(\max )\left(^{\circ}\right)$ & & & & \\
\hline Reflections measured & & & & \\
\hline Unique reflections & & & & \\
\hline$R_{\text {int }}$ & & & & \\
\hline Reflections with $F^{2}>2 \sigma\left(F^{2}\right)$ & & & & \\
\hline Number of parameters & & & & \\
\hline$R_{1}\left[F^{2}>2 \sigma\left(F^{2}\right)\right]$ & & & & \\
\hline$w R 2$ (all data) & & & & \\
\hline GOOF, $S$ & & & & \\
\hline Largest difference peak and hole $\left(\mathrm{e} \AA^{-3}\right)$ & 0.42 & -0.39 & 2.79 & 0.91 \\
\hline
\end{tabular}

\section{Conclusions}

In conclusion, we have utilized iodoanilines to access and stabilize zig-zag chains or ladders incorporating organometallic molybdenum fragments. Amine or organoimido species can be accessed depending on conditions for the 3- and 4-iodoanilines; for the 2-iodoaniline, only an imido product could be isolated. Use of 4-fluoro-2-idoaniline was more sensitive, and both $\mathrm{Mo}(\mathrm{V})$ and $\mathrm{Mo}(\mathrm{VI})$ imido complexes were accessible, the latter 
via adventitious oxidation. All structures exhibit a variety of intermolecular interactions. In terms of ROP, the substituent pattern of the iodo substituents strongly influences the polymerization rate. A meta-iodo substituent is favoured, and it is assumed that the presence of this electron withdrawing group promotes the ability of the metal to perform a nucleophilic attack at the carbonyl of the $\varepsilon$-caprolactone.

Supplementary Materials: The following are available online at https:/ /www.mdpi.com/article/ 10.3390/catal11121554/s1, Figure S1: Alternative views of 1, Figure S2: Views of the molecular structure of [2-I- $-\mathrm{NH}_{3} \mathrm{C}_{6} \mathrm{H}_{4}$ ] Cl, Figure S3: Packing of the complex 2.MeCN, Figure S4: Packing views of 3, Figure S5: Different views of [3-I- $\mathrm{NH}_{3} \mathrm{C}_{6} \mathrm{H}_{4}$ ] Cl, Figure S6: Different views of the packing of 4, Figure S7: Packing of the complex 5, Figure S8: Alternative view and packing for 6.MeCN, Figure S9: Packing of complex 7, Figure S10: Packing of the aniline complex 8, Figure S11: ${ }^{1} \mathrm{H}$ NMR spectrum $\left(\mathrm{CDCl}_{3}, 400 \mathrm{MHz}, 298 \mathrm{~K}\right)$ of the PCL synthesized with $3 / \mathrm{BnOH}$ at $130{ }^{\circ} \mathrm{C}$ under $\mathrm{N}_{2}$ (entry 7, Table 1 ), Figure S12: Mass spectra of the PCL synthesized with 2/BnOH (entry 2, Table 1), Figure S13: Mass spectra of the PCL synthesized with $2 / \mathrm{BnOH}$ (entry 2, Table 2), Figure S14: Mass spectra of the PCL synthesized with 2/BnOH (entry 5, Table 3), Figure S15: Kinetics of 8 versus 2.

Author Contributions: Conceptualization, C.R.; methodology, C.R.; formal analysis, C.R. and T.X.; investigation, C.R. and T.X.; writing-original draft preparation, C.R. and M.R.J.E.; writing-review and editing, C.R. and M.R.J.E.; supervision, C.R.; Crystallography M.R.J.E. and S.H.D.; project administration, C.R.; funding acquisition, C.R. All authors have read and agreed to the published version of the manuscript.

Funding: This research was funded by UKRI Creative Circular Plastic grant (EP/S025537/1). The Chinese Scholarship Council is thanked for awarding a Ph.D. scholarship to T.X.

Acknowledgments: The EPSRC National Crystallographic Service Centre at Southampton is thanked for data. Data for $\mathbf{1}$ were collected at Daresbury Laboratory Station 9.8, whilst mass spectra of the complexes were collected at the National Mass Spectrometry Facility at Swansea University or at the University of Hull. Mass spectra of the PCL samples were collected by Mass and Wyatt Analytical Ltd.

Conflicts of Interest: There are no conflict of interest to declare.

\section{References}

1. Schrock, R.R.; Hoveyda, A.H. Molybdenum and tungsten imido alkylidene complexes as efficient olefin-metathesis catalysts. Angew. Chem. Int. Ed. 2003, 42, 4592-4633. [CrossRef]

2. Gibson, V.C.; Redshaw, C.; Clegg, W.; Elsegood, M.R.J. Synthesis and characterization of molybdenum complexes bearing highly functionalized imido substituents. J. Chem. Soc. Dalton Trans. 1997, 18, 3207-3212. [CrossRef]

3. Redshaw, C.; Wilkinson, G.; Sweet, T.K.N.; Hursthouse, M.B. Synthesis and X-ray structure of the organotungsten(V) o-phenylene diamido complex $\left(\eta-\mathrm{C}_{5} \mathrm{Me}_{5}\right) \mathrm{WCl}_{2}\left\{1,2-(\mathrm{HN})_{2} \mathrm{C}_{6} \mathrm{H}_{4}\right\}$. Polyhedron 1993, 12, 2417-2420. [CrossRef]

4. Redshaw, C.; Gibson, V.C.; Clegg, W.; Edwards, A.J.; Miles, B. Pentamethylcyclopentadienyl tungsten complexes containing imido, hydrazido and amino acid derived N-O chelate ligands. J. Chem. Soc. Dalton Trans. 1997, 18, 3343-3347. [CrossRef]

5. Redshaw, C.; Wood, P.T.; Elsegood, M.R.J. Synthesis and structure of pentamethylcyclopentadienyl tungsten(V) complexes containing functionalized 6,12-epiiminodibenzo[b,f][1.5]diazocine ligands. Organometallics 2007, 26, 6501-6504. [CrossRef]

6. Murray, R.C.; Blum, L.; Liu, A.H.; Schrock, R.R. Simple routes to mono( $\eta^{5}$-pentamethylcyclopentadienyl) complexes of molybdenum(V) and tungsten(VI). Organometallics 1985, 4, 953-954. [CrossRef]

7. Radius, U.; Sundermeyer, J. Organometall-Imide-Höhervalente Derivate der d-Metall-Säure, 2. Alkyl-, Aryl- und Cyclopentadienyl-substituierte Molybdän(VI)- und Wolfram(VI)-Imide. Chem. Ber. 1992, 125, 2183-2186. [CrossRef]

8. Sundermeyer, J.; Radius, U.; Burschka, C. Organometall-Imide-Höhervalente Derivate der d-Metall-Säuren, 3. Synthese und Reaktionen von (Pentamethylcyclopentadienyl)(imido)-Komplexen des Molybdäns und Wolframs und eine effiziente Strategie zur Synthese der Organometallate $\mathrm{NBu}_{4}\left[\mathrm{Cp}^{*} \mathrm{MO}_{3}\right](\mathrm{M}=\mathrm{Mo}, \mathrm{W})$. Chem. Ber. 1992, 125, 2379-2384. [CrossRef]

9. Abugideiri, F.; Brewer, G.A.; Desai, J.U.; Gordon, J.C.; Poli, R. (Pentamethylcyclopentadienyl)molybdenum(IV) chloride. Synthesis, Structure, and Properties. Inorg. Chem. 1994, 33, 3745-3751. [CrossRef]

10. Köhler, K.; Roesky, H.W.; Herzog, A.; Gornitzka, H.; Steiner, A.; Usón, I. Syntheses, Structures, and Reactivity of a Series of (Pentamethylcyclopentadienyl)molybdenum(V) and Tungsten(V) Imido Complexes. Inorg. Chem. 1996, 35, 1773-1777. [CrossRef]

11. Pedraz, T.; Pellinghelli, M.A.; Royo, P.; Tiripicchio, A.; Vázquez de Miquel, A. Preparation of imido pentamethylcyclopentadienyl molybdenum(IV) complexes X-ray molecular structure of $c$ is-[MoCp $\left.{ }^{*} \mathrm{Cl}\left(\mu-\mathrm{N}^{\mathrm{t} B u}\right)\right]_{2} \cdot \mathrm{C}_{6} \mathrm{H}_{6}$. J. Organomet. Chem. 1997, 534, 27-33. [CrossRef] 
12. Sal, P.G.; Jiménez, I.; Martín, A.; Pedraz, T.; Royo, P.; Sellés, A.; Vázquez de Miguel, A. Synthesis of chloro and methyl imido cyclopentadienyl molybdenum and tungsten complexes. X-ray molecular structures of $\left[\mathrm{WCP}^{*} \mathrm{Cl}_{3}(\mathrm{~N} t \mathrm{Bu})\right],[\mathrm{MoCp} * \mathrm{ClMe} 2(\mathrm{~N} t \mathrm{Bu})]$ and $\left[\mathrm{WCp}^{*} \mathrm{ClMe}_{2}(\mathrm{~N} t \mathrm{Bu})\right]$. Inorg. Chimia Acta 1998, 273, 270-278.

13. Kubo, M.; Nakanishi, M.; Kimura, M. Process for the Preparation of Lactone Polyesters. Germany Patent No. DE2947978, 15 September 1981.

14. Báez, J.E.; Martǐnez-Rosales, M.; Martǐnez-Richa, A. Ring-opening polymerization of lactones catalyzed by decamolybdate anion. Polymer 2003, 44, 6767-6772. [CrossRef]

15. Báez, J.E.; Martinnez-Richa, A. Synthesis and characterization of poly( $\varepsilon$-caprolactone) and copolyesters by catalysis with molybdenum compounds: Polymers with acid-functional asymmetric telechelic architecture. Polymer 2005, 46, 12118-12129. [CrossRef]

16. Báez, J.E.; Marcos-Fernández, A.; Martǐnez-Richa, A. One-step route to $\alpha$-hydroxyl- $\omega$-(carboxylic acid) polylactones using catalysis by decamolybdate anion. Macromolecules 2005, 38, 1599-1608. [CrossRef]

17. Mahha, Y.; Atlamsani, A.; Blais, J.-C.; Tessier, M.; Brégeault, J.M.; Salles, L. Oligomerization of $\varepsilon$-caprolactone and $\delta$-valerolactone using heteropolyacid initiators and vanadium or molybdenum complexes. J. Mol. Catal. A Chem. 2005, 234, 63-73. [CrossRef]

18. Reyes-López, S.Y.; Richa, A.M. The ring-opening polymerization of $\varepsilon$-caprolactone catalyzed by molybdenum trioxide: A kinetic approach study using NMR and DSC data. Macromol. Symp. 2013, 325-326, 21-37. [CrossRef]

19. Maruta, Y.; Abiko, A. Bis(salicylaldehydato)dioxomolybdenum complexes: Catalysis for ring-opening polymerization. Polym. Bull. 2014, 71, 1433-1440. [CrossRef]

20. Yang, W.; Zhao, Q.-K.; Redshaw, C.; Elsegood, M.R.J. Molybdenum complexes derived from the oxydianiline $\left[\left(2-\mathrm{NH}_{2} \mathrm{C}_{6} \mathrm{H}_{4}\right)_{2} \mathrm{O}\right]$ : Synthesis, characterization and $\varepsilon$-caprolactone ROP capability. Dalton Trans. 2015, 44, 13133-13140. [CrossRef]

21. Al-Khafaji, Y.; Prior, T.J.; Elsegood, M.R.J.; Redshaw, C. Molybdenum(VI) imido complexes derived from chelating phenols: Synthesis, characterization and $\varepsilon$-caprolactone ROP capability. Catalysts 2015, 5, 1928-1947. [CrossRef]

22. Sun, Z.; Zhao, Y.; Prior, T.J.; Elsegood, M.R.J.; Wang, K.; Xing, T.; Redshaw, C. Mono-oxo molybdenum(VI) and tungsten(VI) complexes bearing chelating aryloxides: Synthesis, structure and ring opening polymerization of cyclic esters. Dalton Trans. 2019, 48, 1454-1466. [CrossRef]

23. Cavallo, G.; Metrangolo, P.; Milani, R.; Pilati, T.; Priimagi, A.; Resnati, G.; Terraneo, G. The halogen bond. Chem. Rev. 2016, 116, 2478-2601. [CrossRef] [PubMed]

24. Bulfield, D.; Engelage, E.; Mancheski, L.; Stoesser, J.; Huber, S.M. Crystal engineering with multipoint halogen bonding: Double two-point donors and acceptors at work. Chem. Eur. J. 2020, 26, 1567-1575. [CrossRef] [PubMed]

25. Dumitrescu, D.; Shova, S.; Man, I.C.; Caira, M.R.; Popa, M.M.; Dumitrascu, F. 5-Iodo-1-arylpyrazoles as potential benchmarks for investigating the tuning of the halogen bonding. Crystals 2020, 10, 1149. [CrossRef]

26. Kawakita, K.; Kakiuchi, Y.; Tsurugi, H.; Mashima, K.; Parker, B.F.; Arnold, J.; Tonks, I.A. Reactivity of terminal imido complexes of group 4-6 metals: Stoichiometric and catalytic reactions involving cycloaddition with unsaturated organic molecules. Coord. Chem. Rev. 2020, 407, 213118. [CrossRef]

27. Nugent, W.A.; Haymore, B.L. Transition metal complexes containing organoimido (nr) and related ligands. Coord. Chem. Rev. 1980, 31, 123-175. [CrossRef]

28. Sheldrick, G.M. SHELXT-Integrated space-group and crystal structure determination. Acta Crystallogr. Sect. A Found. Adv. 2015, A71, 3-8. [CrossRef] [PubMed]

29. Sheldrick, G.M. Crystal structure refinement with SHELXL. Acta Crystallogr. Sect. C Struct. Chem. 2015, C71, 3-8. [CrossRef] 